Journal of Social Sciences (COES\&RJ-JSS)

ISSN (E): 2305-9249 ISSN (P): 2305-9494

Publisher: Centre of Excellence for Scientific \& Research Journalism, COES\&RJ LLC

Online Publication Date: $1^{\text {st }}$ January 2016

Online Issue: Volume 5, Number 1, January 2016

http://centreofexcellence.net/J/JSS/JSS\%20Mainpage.htm

\title{
The degree of heads of departments at the University of Dammam to practice transformational leadership style from the point of view of the faculty members
}

Dr. Saddam Rateb Mahmoud Darawsheh *, Dr. Anwar Soud ALshaar **, Dr. Ra'ed (Moh'd Taisir) Masa'deh***, Prof. Musa Al-Lozi****

* Assistant Professor in the preparatory year / University of Dammam, KSA, srdarawseheh@uod.edu.sa

** Assistant Professor in the preparatory year / University of Dammam, KSA, anwar.shaar@yahoo.com

*** Associate Professor of Management Information Systems Department, School of Business, The University of Jordan, r.masadeh@ju.edu.jo

**** Vice President for Humanities Faculties Affairs, The University of Jordan, Amman, Jordan, Lozi.musa@ju.edu.jo

\begin{abstract}
:
This study aimed to identify the degree of heads of departments in the University of Dammam in KSA to conduct transformational leadership approach from the point of view of faculty members, and to achieve that the researchers used the descriptive method which is used for the diagnosis of facts by utilizing a questionnaire tool, by which the study population consisted of all the academic staff from all departments at the University of Dammam accounted 2100, however, by using simple random sampling techniques 300 valid returned questionnaires were took into consideration for the analysis. The study found the degree to which the practice of heads of departments in the University of Dammam for the transformational leadership style from the viewpoint of the faculty members was high (i.e. for all the variable's items, except three paragraphs, ranging averages between (3.16- 4.94) out of (5). Also, the results of the statistical analysis showed that there were a statistically significant differences at the level of $\alpha=0.05$ in the responses of faculty members on all paragraphs attributed to the sex in favor to females; whereas neither statistically significant differences at the level of $\alpha=0.05$ found attributed to experience nor to the academic rankings. In light of the results of the study, the researchers purpose a set of recommendations.
\end{abstract}

Key words:

leadership, transformational leadership, heads of departments, faculty members, KSA

Citation:

Darawsheh, Dr. Saddam Rateb Mahmoud; Al-Shaar, Dr. Anwar Soud; Masa'deh, Dr. Ra'ed (Mo'hd Taisir); Al-Lozi, Prof. Musa (2016); The degree of heads of departments at the University of Dammam to practice transformational leadership style from the point of view of the faculty members; Journal of Social Sciences (COES\&RJ-JSS), Vol.5, No.1, pp: 56-79. 


\section{درجة ممارسة رؤساء الأقسام في جامعة الدمام للقيادة التحويلية من وجهة نظر أعضاء هيئة التتريس}

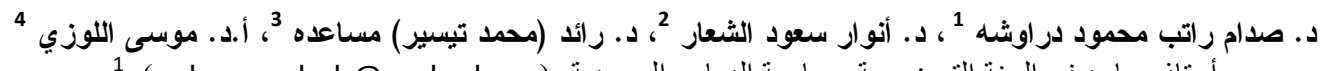

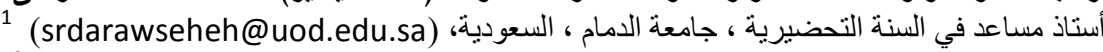

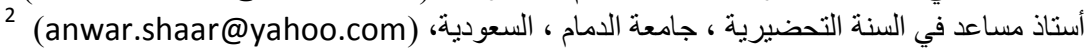

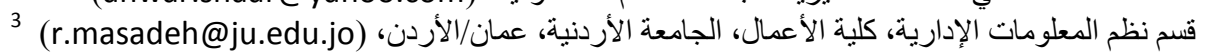

4 نائب رئيس الجامعة الاردنية للثؤون الكليات الانسانية، الجامعة الأردنية، عمان/الأردن، (Lozi.musa@ju.edu.jo)

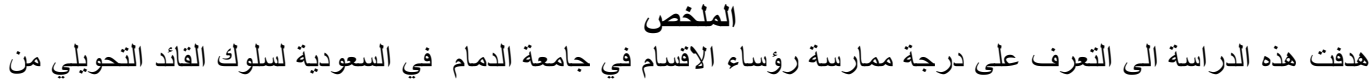

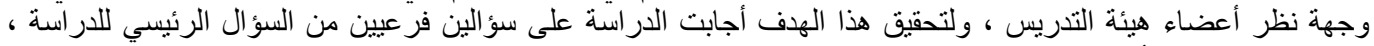

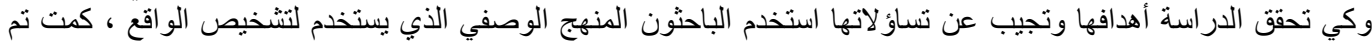

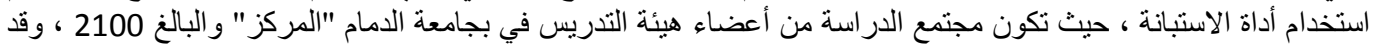

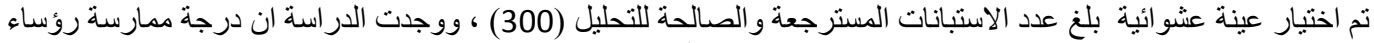

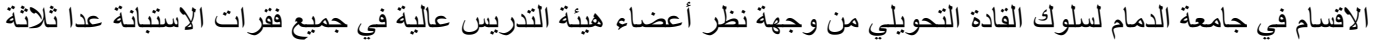

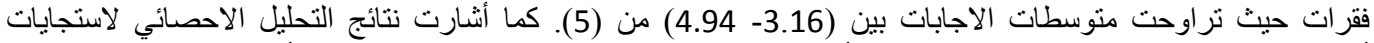

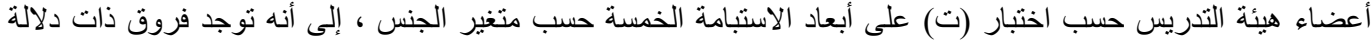

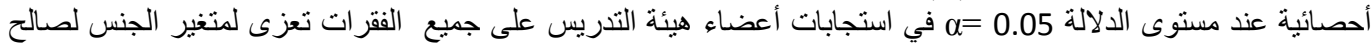

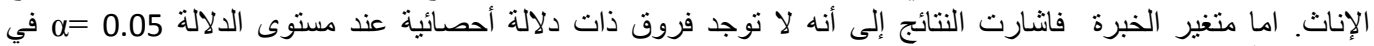

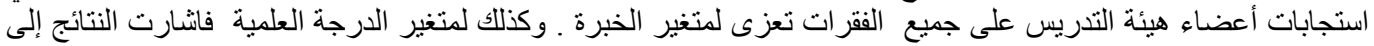

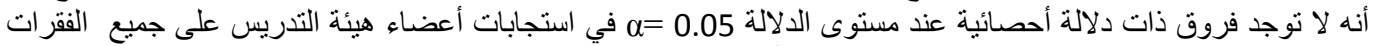

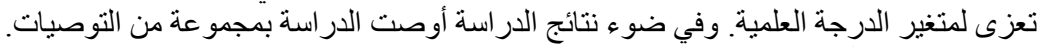

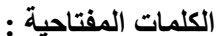

القبادة ، القيادة التحويلية ، رؤساء الاقسام ، أعضاء هيئة التدريس ، السعودية.

المقدمة

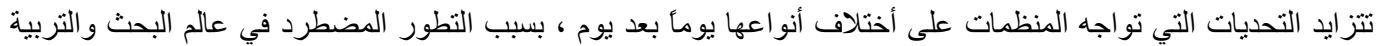

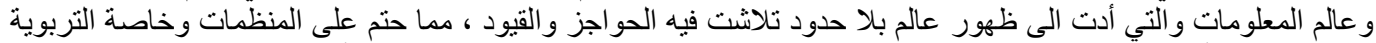

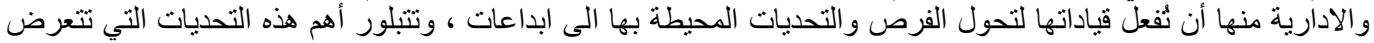

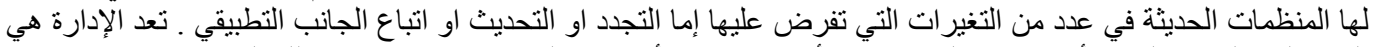

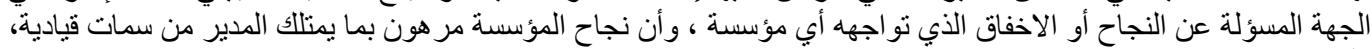

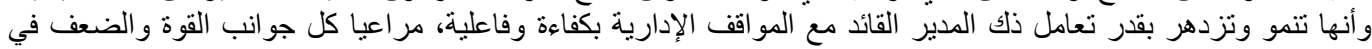

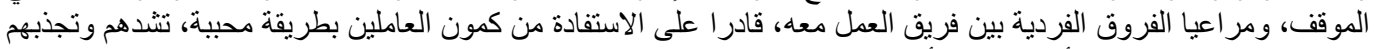

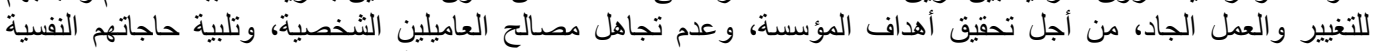

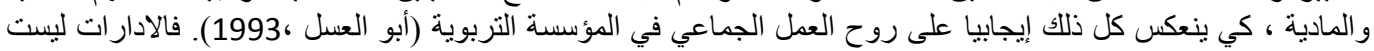

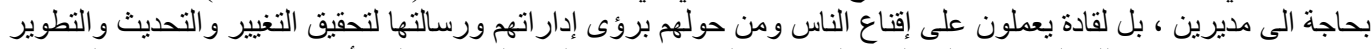

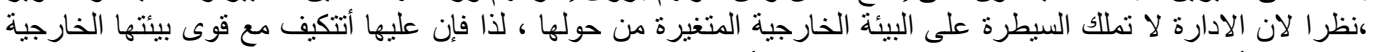
التي تحدث أثر ها من خلال التغييرات الداخلية التي يتوقع أن تسهم بزيادة فاعليتها (Masa'deh et al.,2015).

يرتبط الأداء بمدى فاعلية وكفاءة المؤسسات في تأدية الوظائف وتحقيق الأهداف المنشودة من قيام المؤسسة بشتى مجالاتها

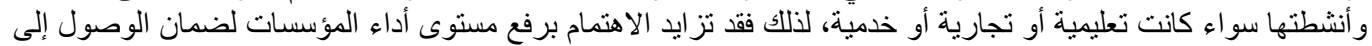

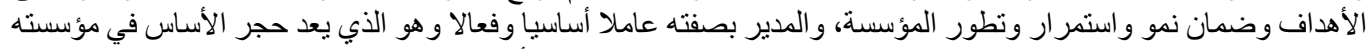

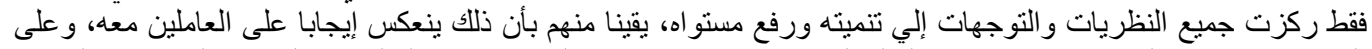

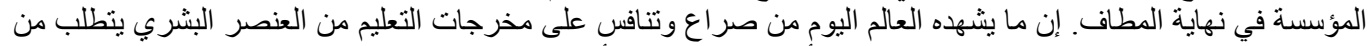

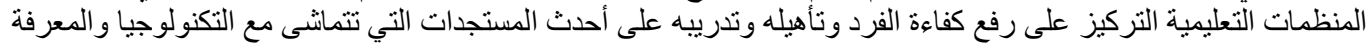

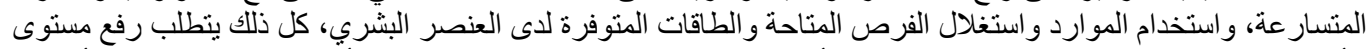

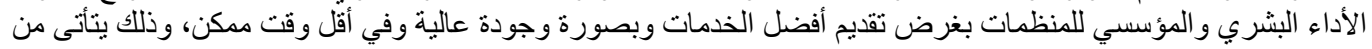




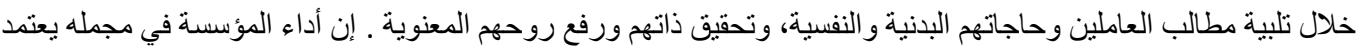

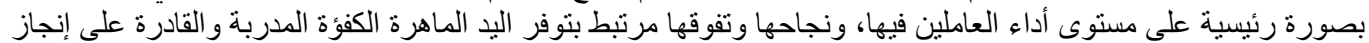

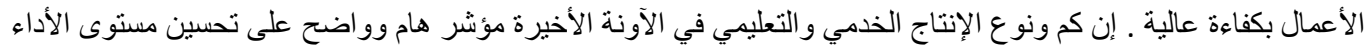

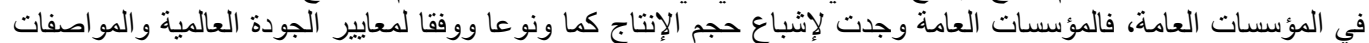

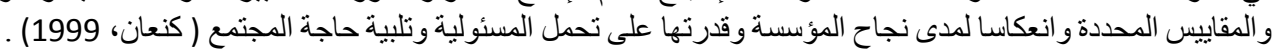

مفهوم القيادة واهميتها:

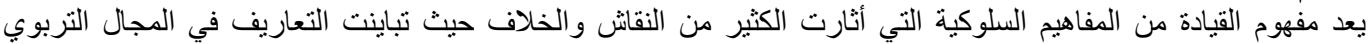

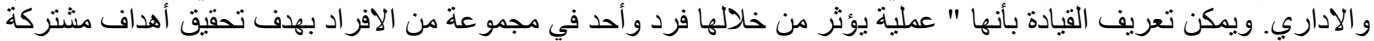

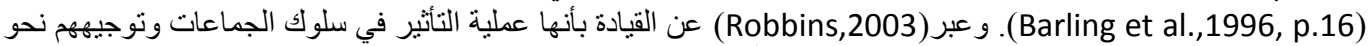

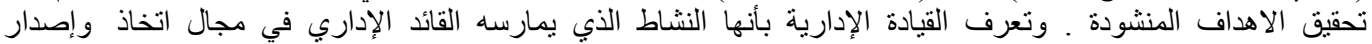

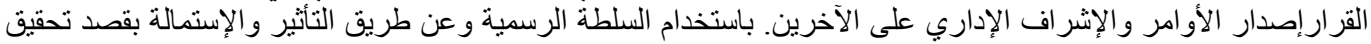

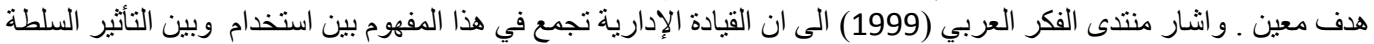

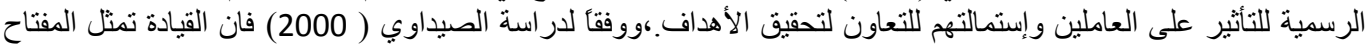

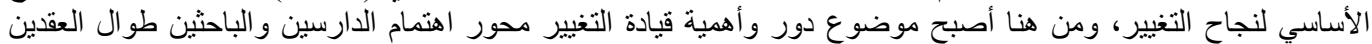
الماضيين. فالقيادة الإدارية تجمع في هذا المفهوم بين استخدام وبين التأثير السلطة الرسمية للتأثير على العاملين وإستينمالتهر

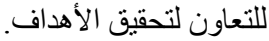

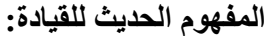

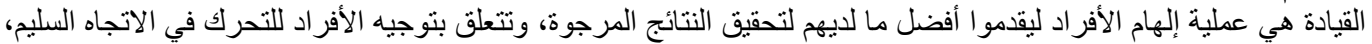

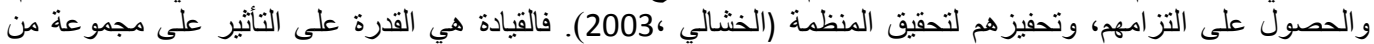

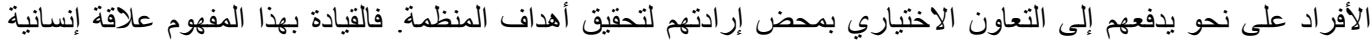

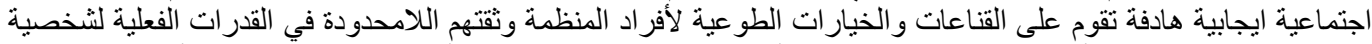

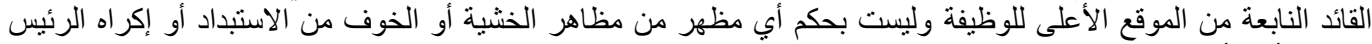

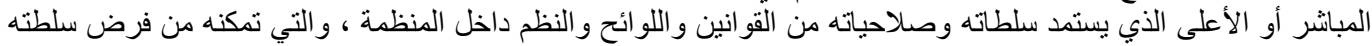

وقدرته على إلز امية مرؤوسيه وإجبار هم على تنفيذ الأو امر ـ استناداً على سلطته (لألى ( Roberts,1985 ).

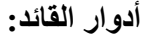
هناك دورين أساسين للقادة يجب عليهم الاهتمام بهما و هما ( برنوطي ،2001):

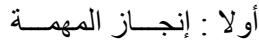

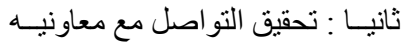
فالقيادة موز عة بين الأفر ادئ وهي لئيت حكر ا على الفرد الذي يتربع على القمة في المنظمة أو الثركة، ولكنها كامنة في أي فرد

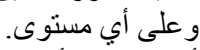

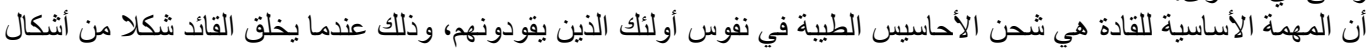

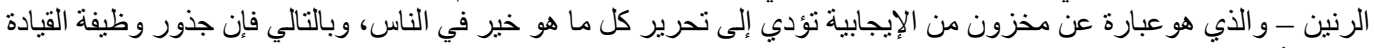

هي في أساسها عاطفية. (الطيان ، 2000).

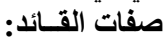
للقائد صفات تميزه عن غيره كما ورد في (جواد ، 2000): 1) أن يكون محنلك وخبير. 2) أن يتعرف على من مون اطن الضعف وخئ ويعمل للقضاء عليها .

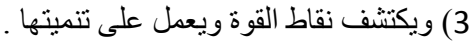

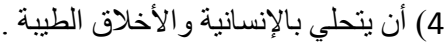
5) لا بميز بين افر اد فريقه أو المجتمع الذي يتولئ لإني قيادته.

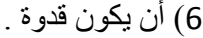

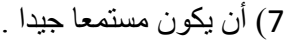
8) ان يحسن اختيار معاونيه ممن يعملو الصالح مجتمعهم فقط .

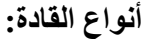
هنالك انواع للقيادة تتبع من فبل الممارسين لهاو هي (ديرولوف،2002): 


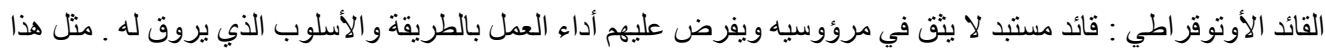

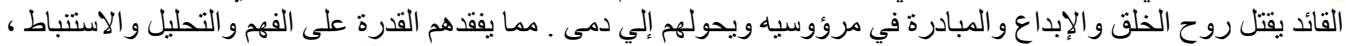

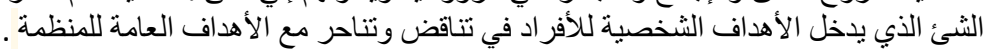

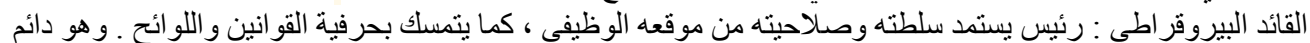

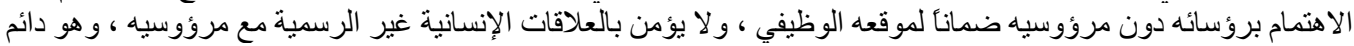

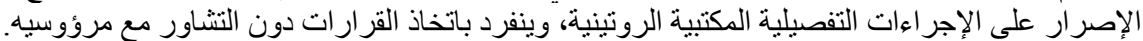
القائد الثورى : قائد يحب التشاور مع مرؤوسيه ولكن في النهاية القرار قراره النهار ولا علاقة له بأي ملاحظات أو مقترحات من

القائد الديمقر اطي : يؤمن بالعلاقات الإنسانية ويتقرب من مرؤوسيه ويتعرف على مشاكلهم ويساعدهم في حلها ويشرك

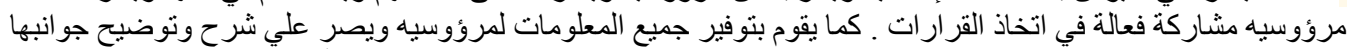

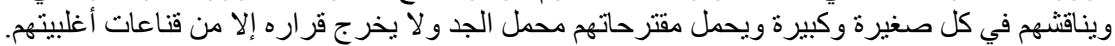

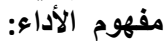

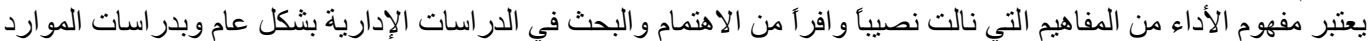

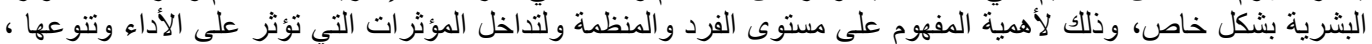

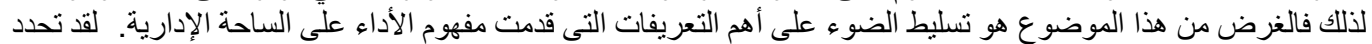

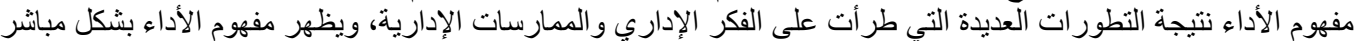

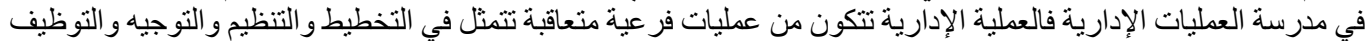

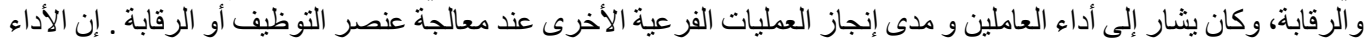

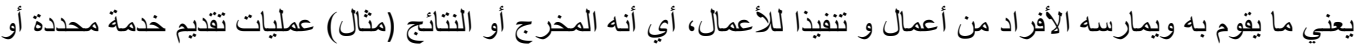

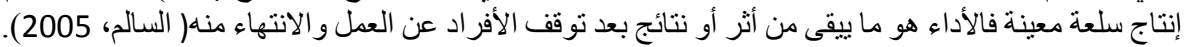

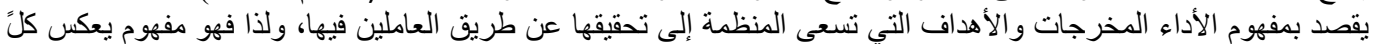

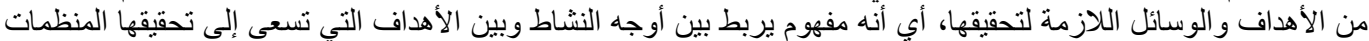

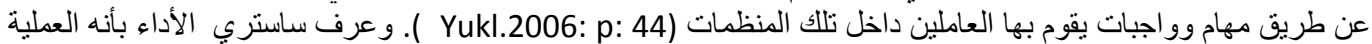

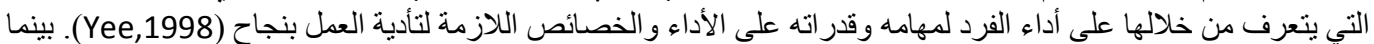

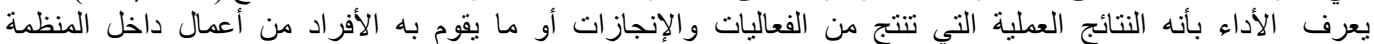

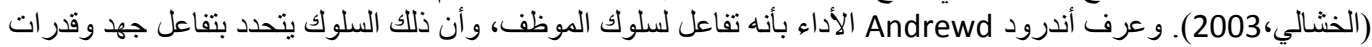

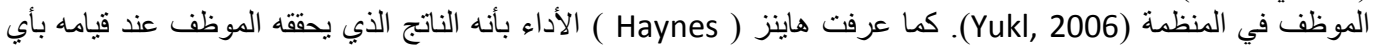

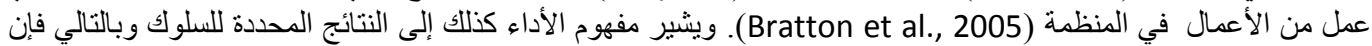

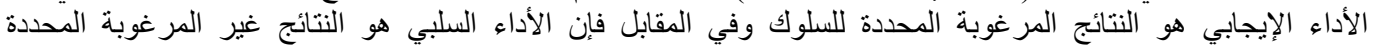

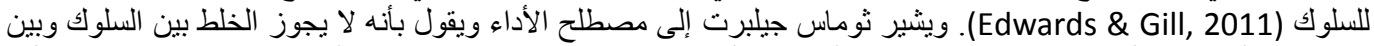

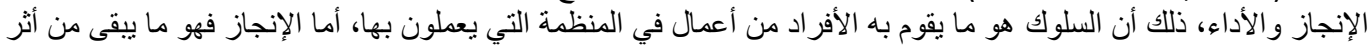

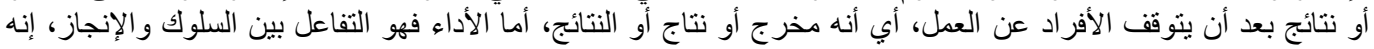

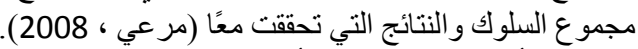

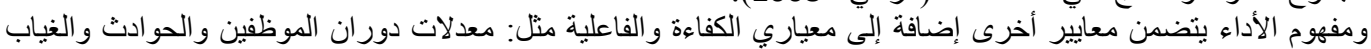

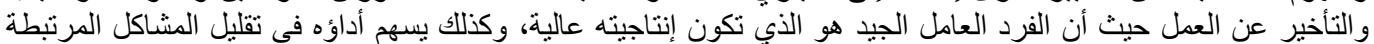

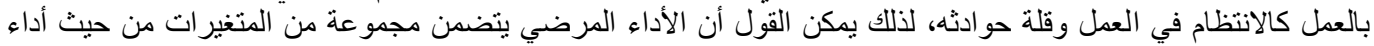

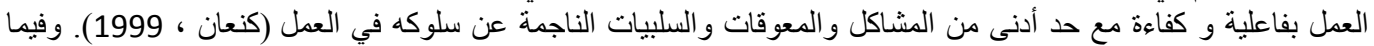

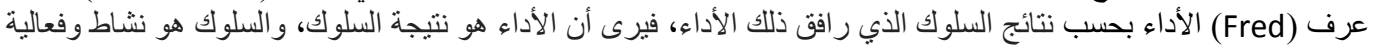

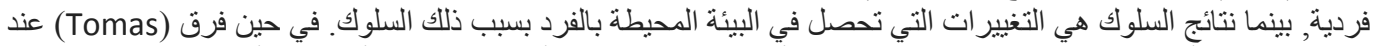

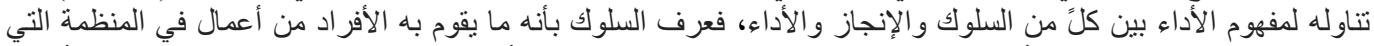

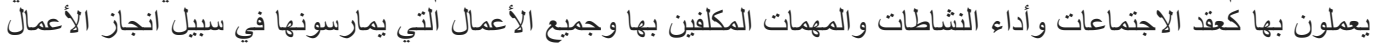

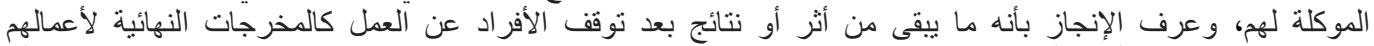

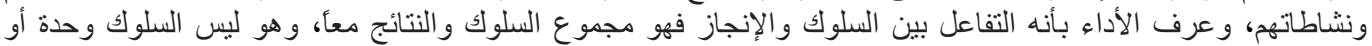

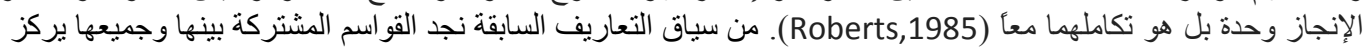

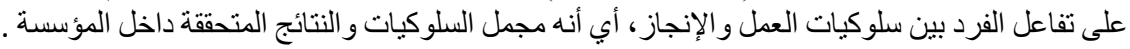

ويرى (أبو العسل ،1999): أن الأداء الناجح يتحقق نتيجة تفاعل عدة عوامل منها : 
Journal of Social Sciences (COES\&RJ-JSS), 5(1), pp.56-79

العوامل البيئية: وتتضمن ظروف العمل المعدات، والمواد و التعليم و الإشراف، إضافة إلي السياسات وتصميم المؤسسة

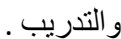
الإمكانيات المتوفرة و القدرة على أداء العمل .

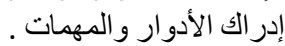
الدافعية الفردية: فمن خلال تفاعل كل تلك العو امل فيما بينها يتحدد مستوى الأداء ، وبالتالي ينعكس على عملية الإنتاج .

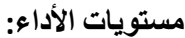
يقسم الهلال (2001) الأداء إلى ثناث مستويات كما يلي:

$$
\text { التخطيط ووضنع الأهداف التفطي }
$$

يتضمن التخطيط تحديد أهداف المرعوسين، ووضع إستراتيجية لتحقيق هذه الأهداف وتشكيل الوسائل لتكامل الأنشطة

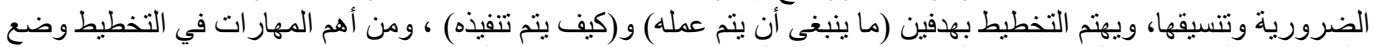

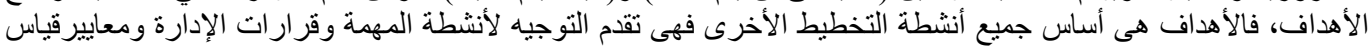

تقييم الأداء ومر اقبته الإنه

من أهم مسؤوليات المدير والتئ تعد أيضا أصعبها ، هى تقييم عمل موظفيه من خلال تقييمات الأداء، فمن خلال تقيهم الأداء،

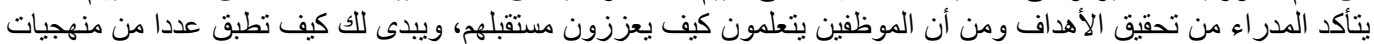

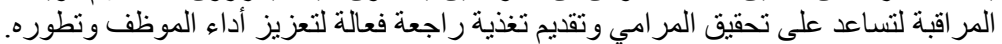
وضع ضو ابط أخلاقية

اتخاذ القرارات الصائبة في المواقفة المبنة المرتبطة بالمسائل الأخلاقية هو أمر يحدث كل يوم تقريبا مع أغلب المدراء، فقرارات

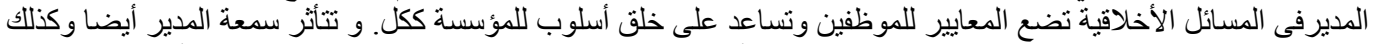

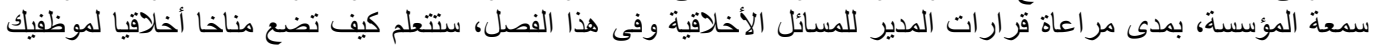

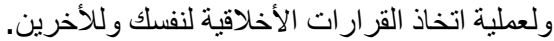

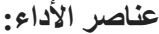

تتنوع العناصر المرتبطة بالأداء و التي يفترض بالعاملين معرفتها والتمكن منها بشكل جيد، ويثير كثير من الباحثين إلى أن

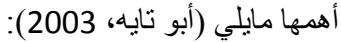
المعرفة بمتطلبات الوظيفة: وتشمل المعارف والئه والمهار ات الفنية و الخلفية العامة عن الوظيفة و المجالات المرتبطة بها.

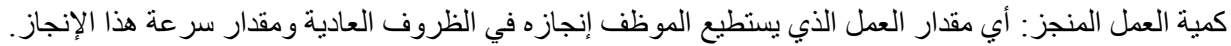

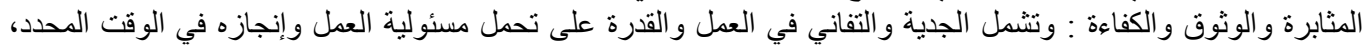
و مدى حاجة الموظف للإرشاد و التوجيه من قبل المشرفين وتقييم نتائج عمله.

مما سبق يتبين أن الكفاءة تهتم وتركز على الكم والنوع في آن واحد، وتعنى بحسن استخدام عناصر الإنتاج من جميع جو انبها

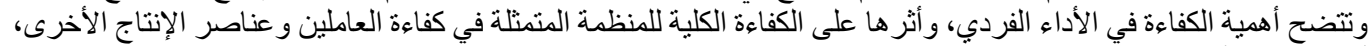

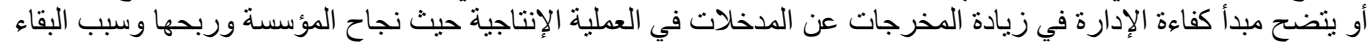

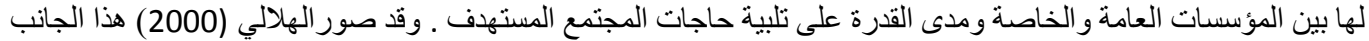

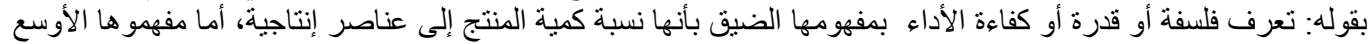

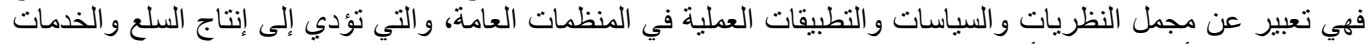

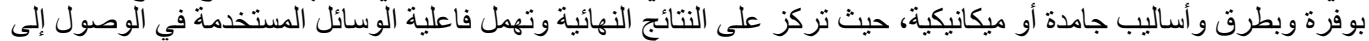

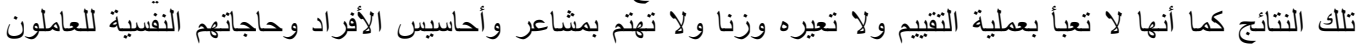

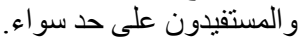

$$
\text { يتأثر الأداء بعأملين على الساسيين هماء(أفوليو،2003): }
$$

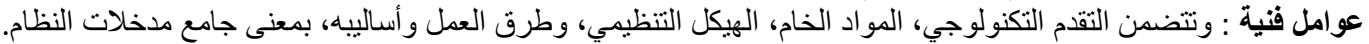

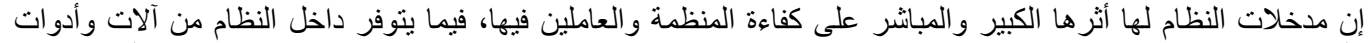

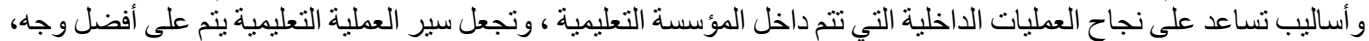
وبالتالي يساهم في مخرجات كفؤة وجيدة . 
عو امل إنسانية : وتتضمن القدرة على الأداء الفعلي للعمل وتتحدد القدرة على الأداء بامتلاك المؤسسة للمعرفة و التعليم و الخبرة،

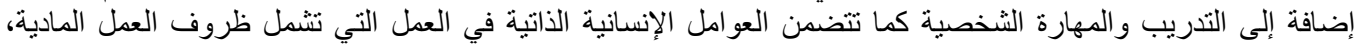

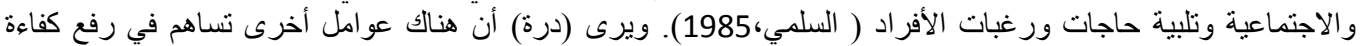

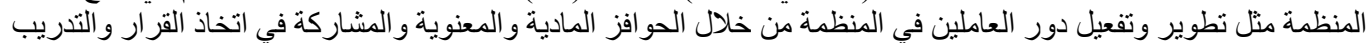

و التأهيل المستمر لهم (درة، 2003 ).

علاقة القيادة التحويلية بالأداء:

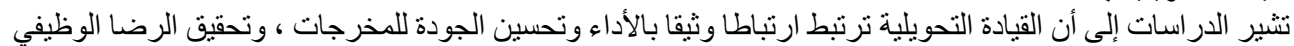

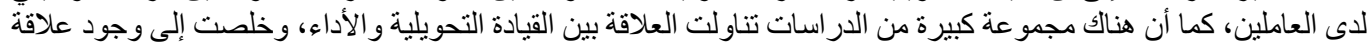

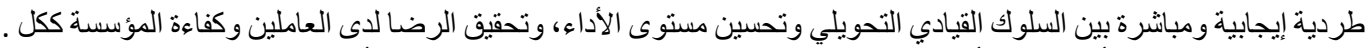

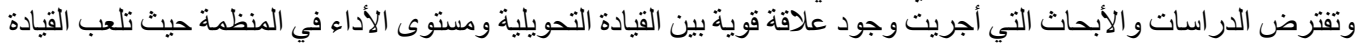

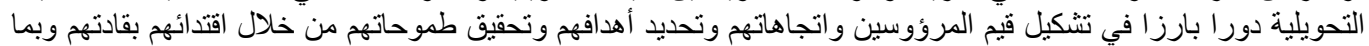

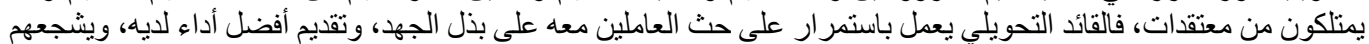

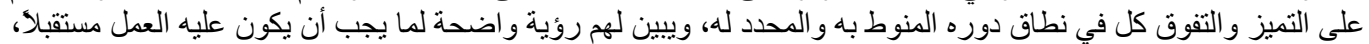

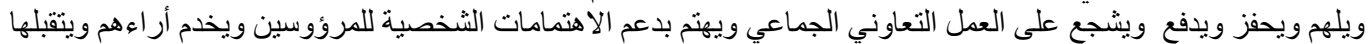

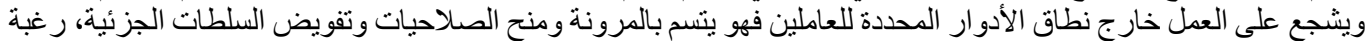

في تحقيق تطلعات المؤسسة قادة و أفر ادا لتحقيق أعلى مستوى من الثقة و الاحتر ام المتبادل. (سمير ان ومقابلة ، 2014).

ويعد مصطلح القيادة التحويلية من الدصطلحات التي ظهرت حديثأ في مجال القيادة، فقد ظهر مصطلح القيادة التحويلية لأول مرة

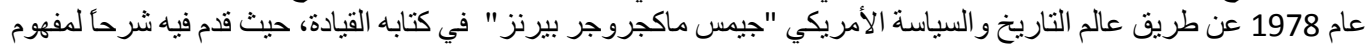

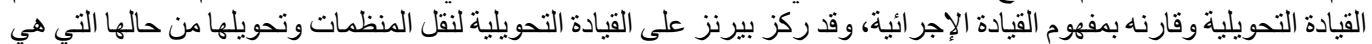

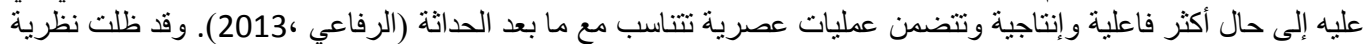

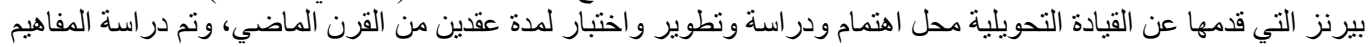

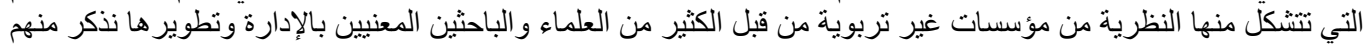

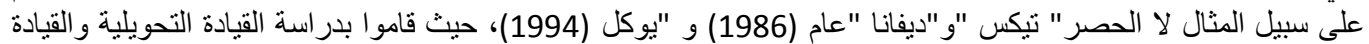

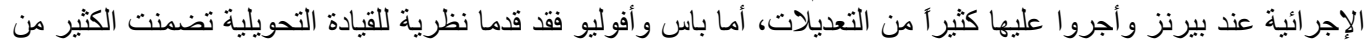

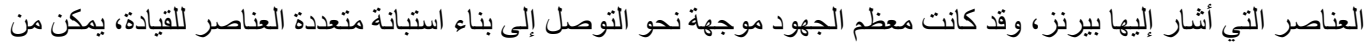

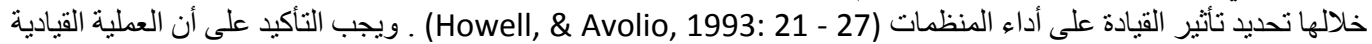

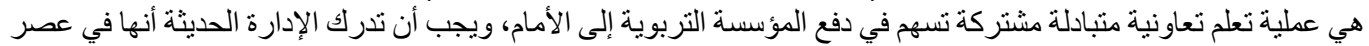

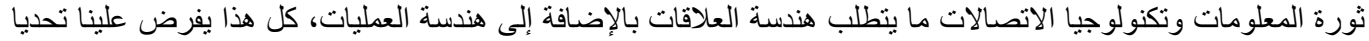

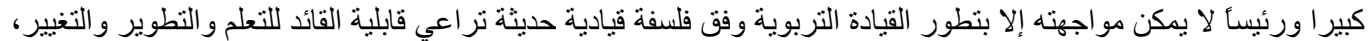

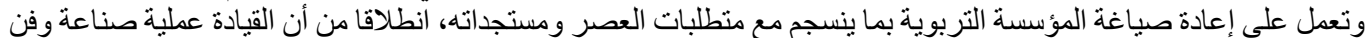

ممكن، بالإمكان إعادة تشكيلها بما يتناسب و الظروف المحيطة بها كي تتمكن من إدارة مؤسسات المستقبل بكفاية وفاعلية .

إن قيادة التغير نمط قيادي يخلق الحماس و الدافعية في نفوس العاملين في المؤسسات التربوية ويدفعهم إلى التغيير ويزر عالمعاد الأمل

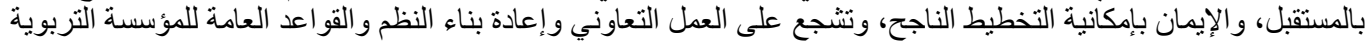

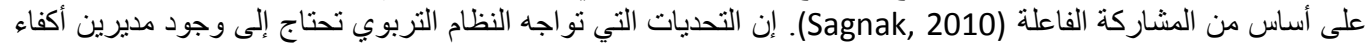

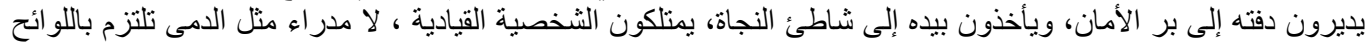

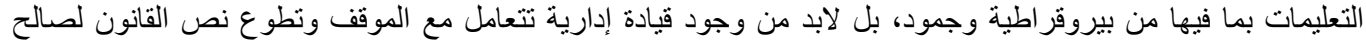

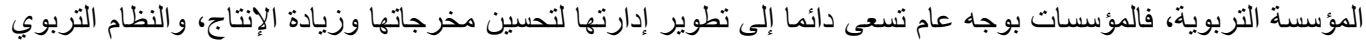

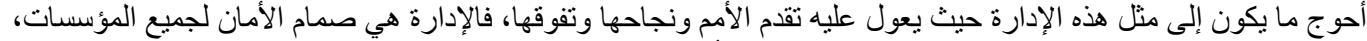

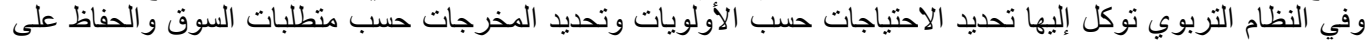

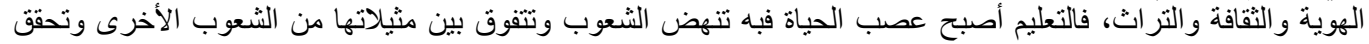

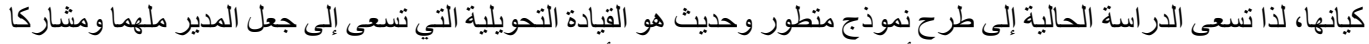

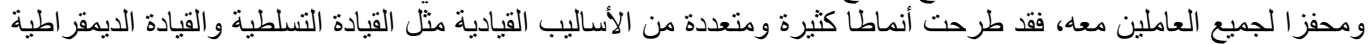

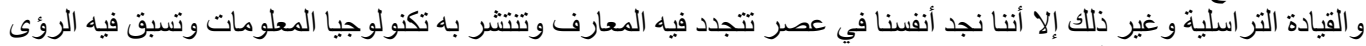

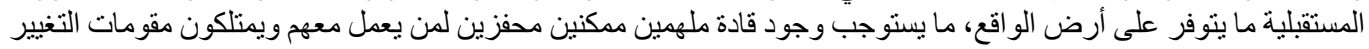


إضافة إلى الرغبة فيه ويتيحون فرصا أمام المرؤوسين لإخر اج إبداعاتهم ومكنونات أنفهم وتوظيف قدراتهم الكامنة لخدمة

وقد أفرزت هذه المتغيرات مجموعة من التحديات التي تواجه المنظمات بشتى أشكالها و أنواعها، خاصة المؤسيسات التعليمية

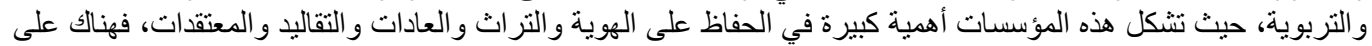

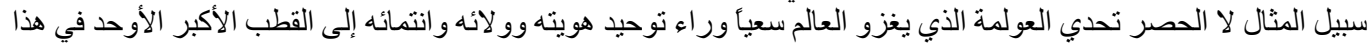

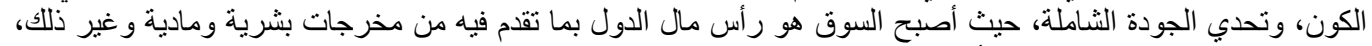

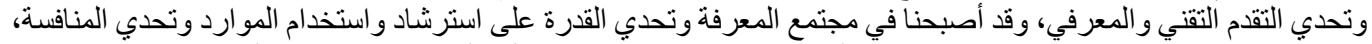

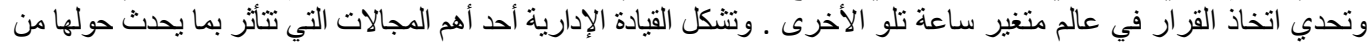

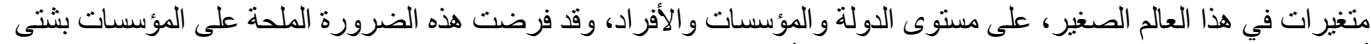

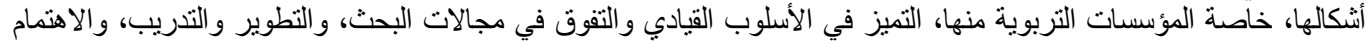

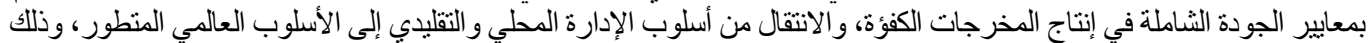

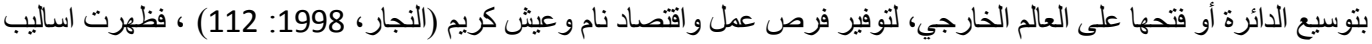

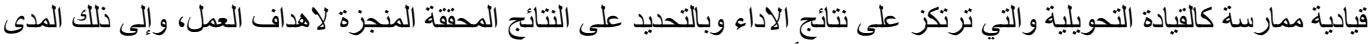

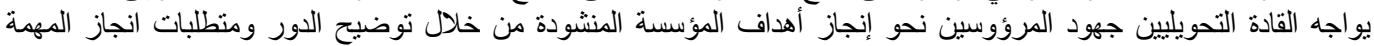

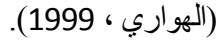

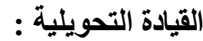

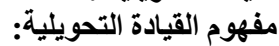

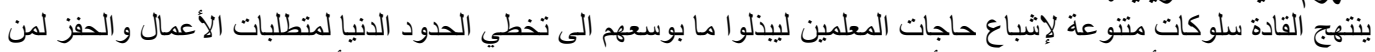

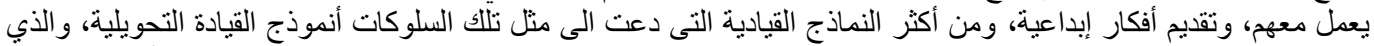

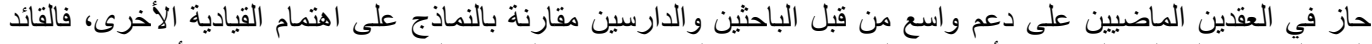

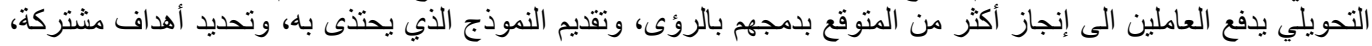

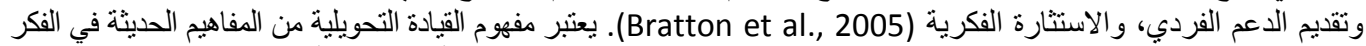

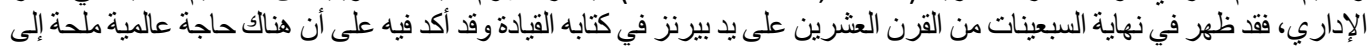

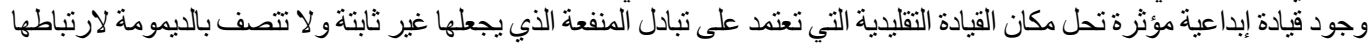

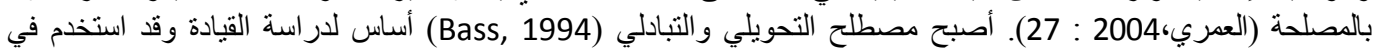

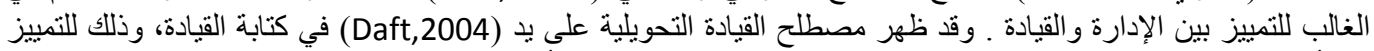

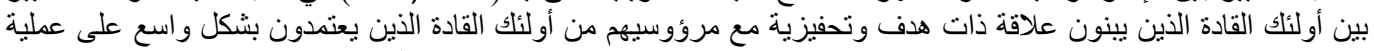

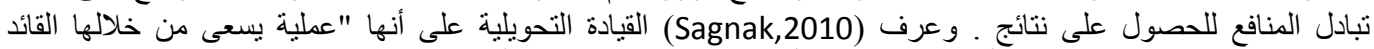

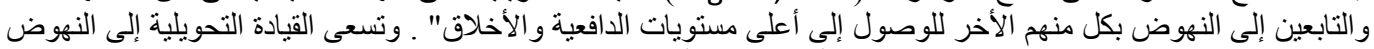

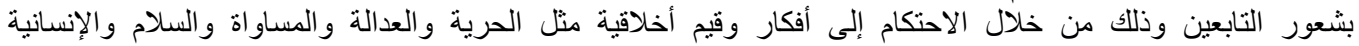
(Bass\&Avolio,1997)

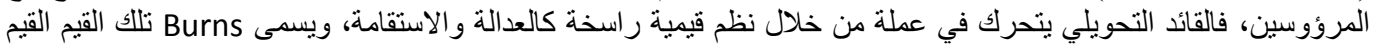

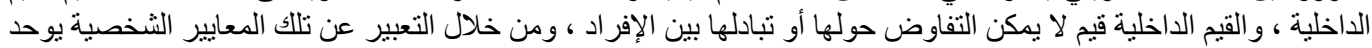

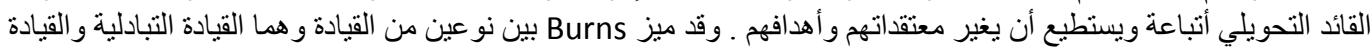

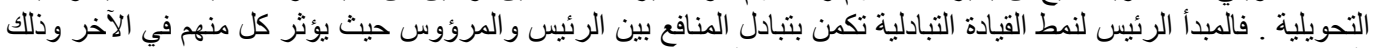

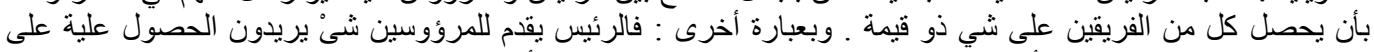

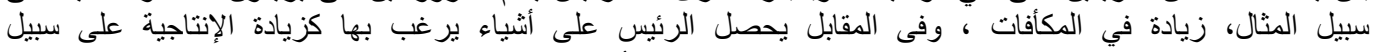

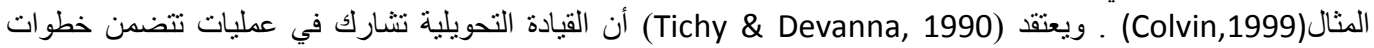

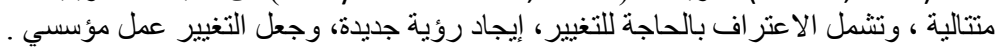

وفى مراجعة ( Podsakoff \& MacKenzie, 1996 (لأدبيات القيادة و التغيير التي تتضمن أيضاً القيادة الجاذبية والتبادلية

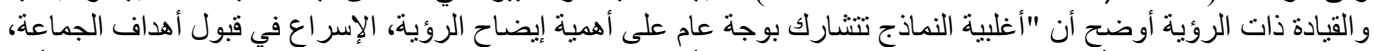

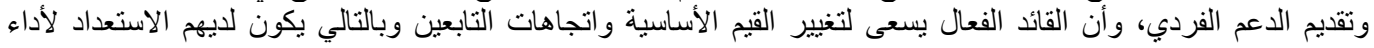

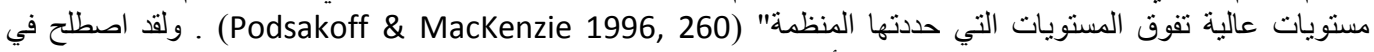

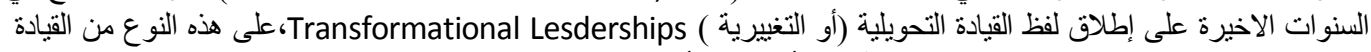
(السالم ، 2005) . ورغم انتثار المفهوم في الآونة الأخيرة إلا أن الغوضية ) الغوض لا يزال يكتنفه، وقد فسرت جوهر القيادة التحويلية 


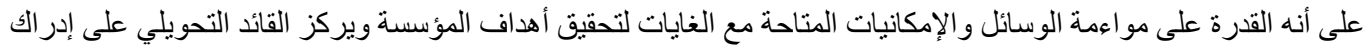

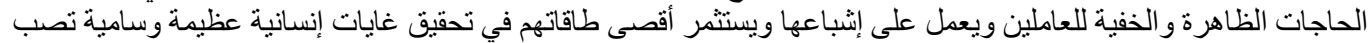

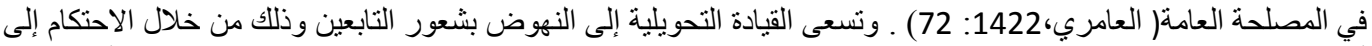

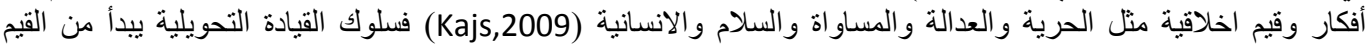

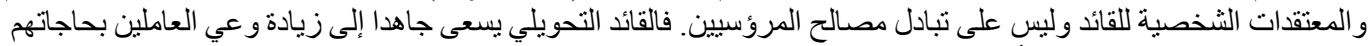

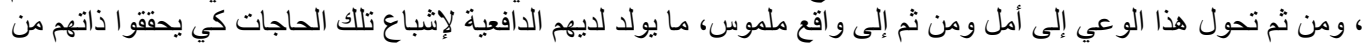

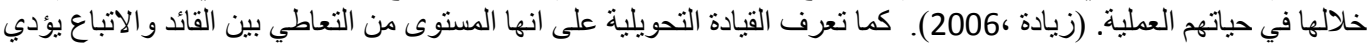

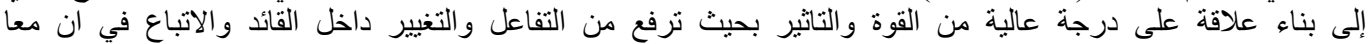

(Bass\&Avolio,1994)

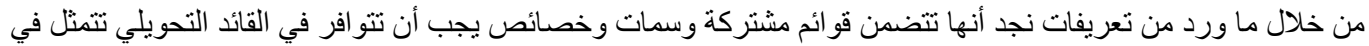

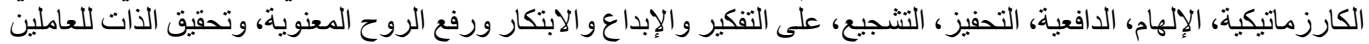

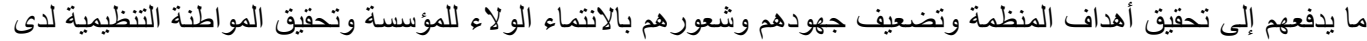

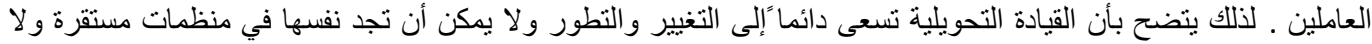

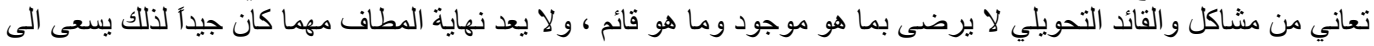

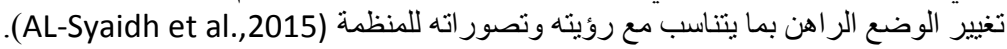

ثنانياً: عناصر القيادة التحويلية (fourt's) - كما أوردها (Edwards \& Gill, 2011) و على النحو

1. التأثير المثالي (الجاذبية): حيث تصف سلوك القائد الذي يحظى بإعجاب واحترام وتقدير التابعين. ويتطلب ذلك اللك

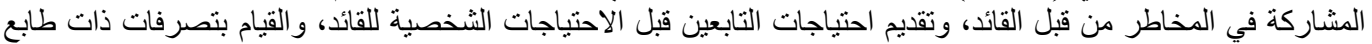

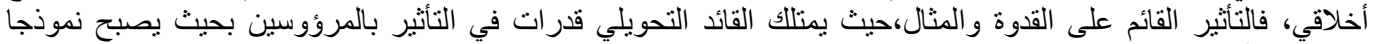

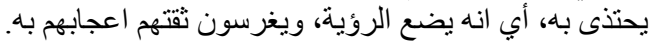

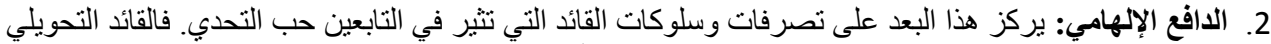

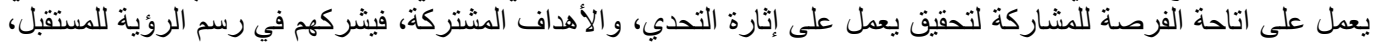

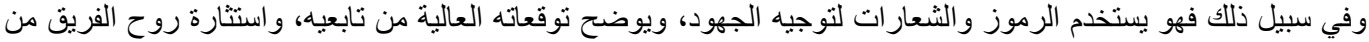

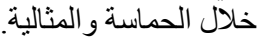

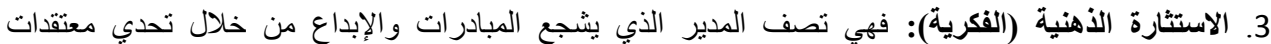

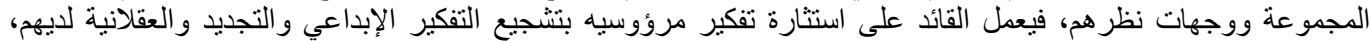

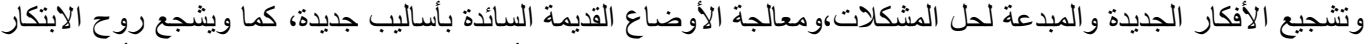

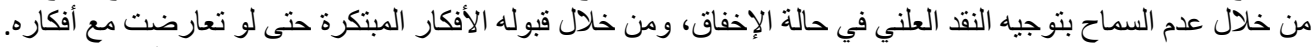

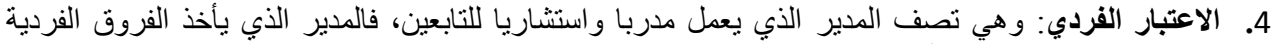

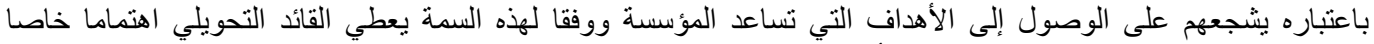

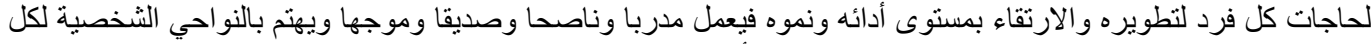

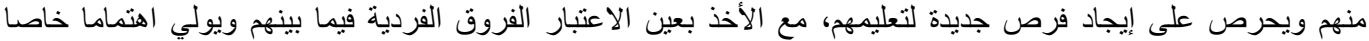

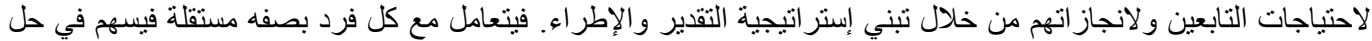

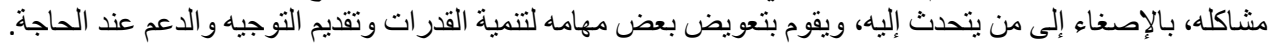

ثالثاً : أبعاد القيادة التحويلية (2014) ان أثنار سمير ان ومقابلة (2014) أن القيادة التحويلية تتضمن أربعة أربعة أبعاد :

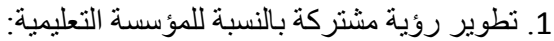

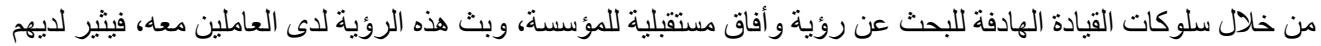

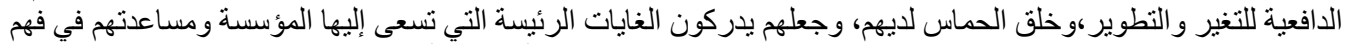

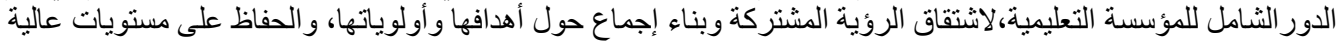

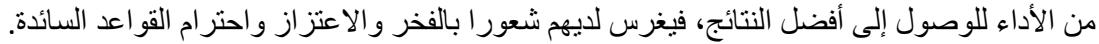

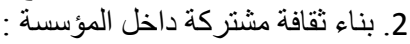




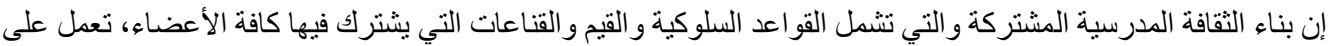

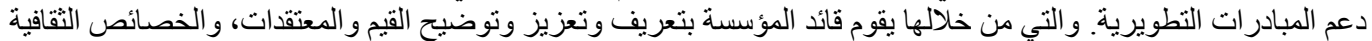

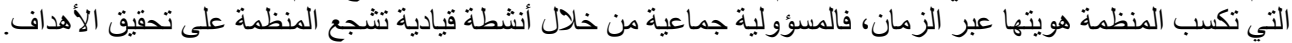

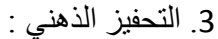

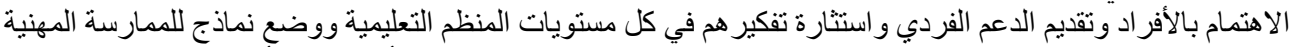

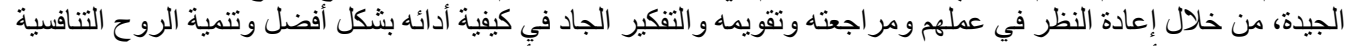

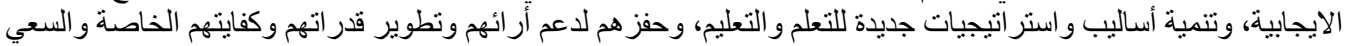

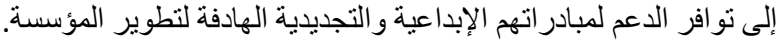

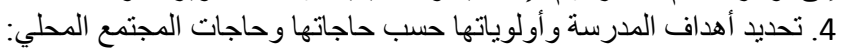

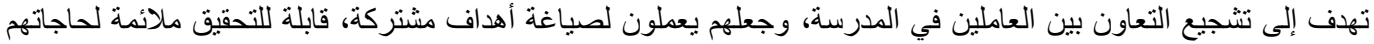

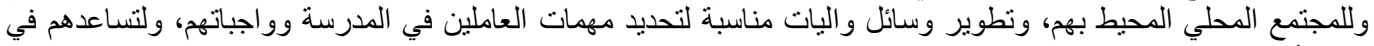
تحديد أهدافهم وبشكل تعاوني بين المدير و العاملين وفق ما يناسب التنياجات المجتمع و الهتماماته.

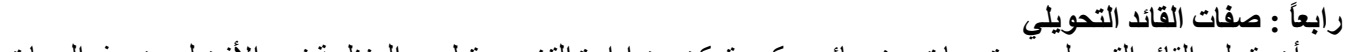
يجب انب يتحلى القائد التحويلي بعدة سمات وحصايص كي يُمكن من إدارة التغيير ونطوير المنظمة نحو الافضل من هذه السمات

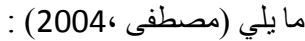
أن يكون صاحب رؤية مستقبلية.

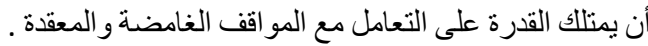

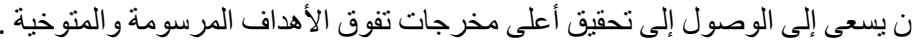

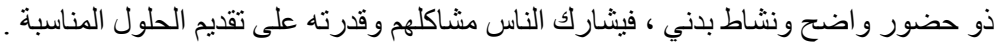

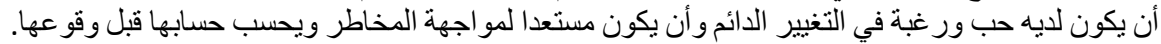

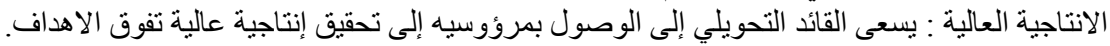

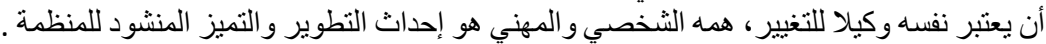

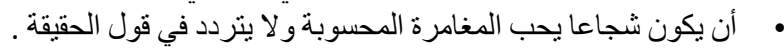

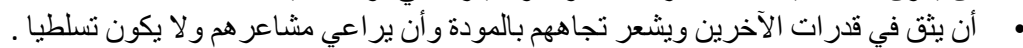

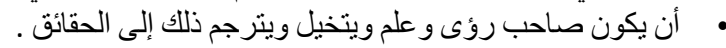

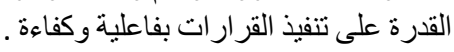
وضع الرؤى و الرسالة و الخطط الإستر اتيجية للمؤسسة والألتز ام بها .

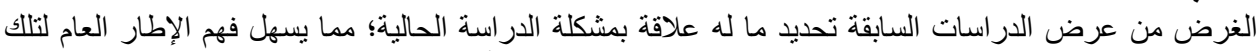

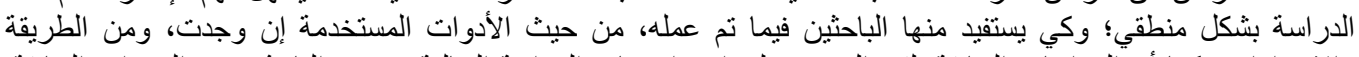

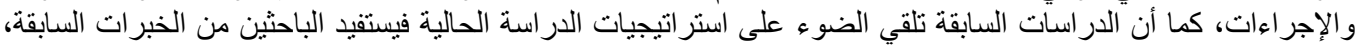

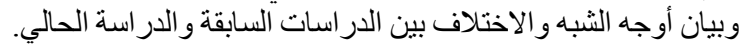

أولا :الاراسات العربية

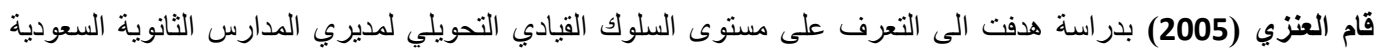

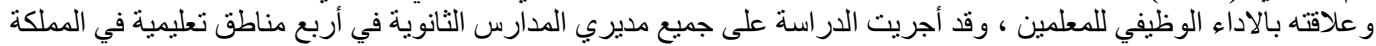

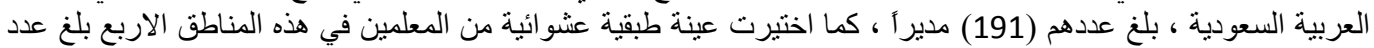

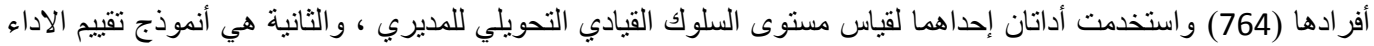

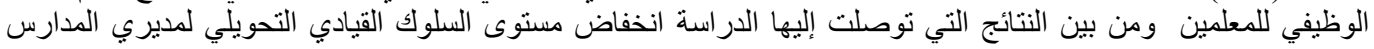

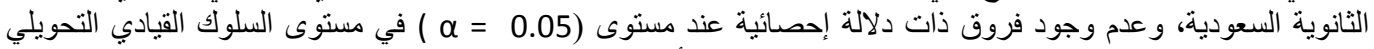

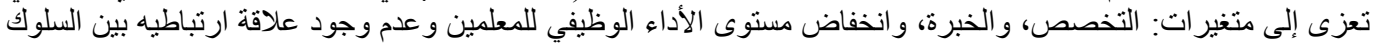
القيادي التحويلي للمديرين و الأداء الوظيفي للمعلمين.

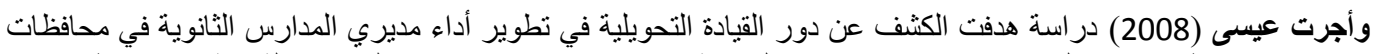

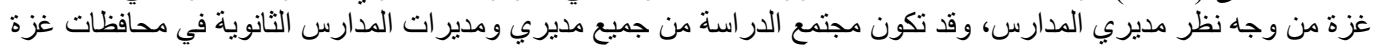

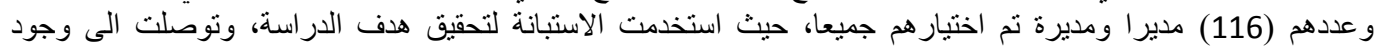


ممارسة للقيادة التحويلية في تطوير أداء مديري المدارس بنسبة اقل من 60\%، و لا توجد فروق ذات دلالة إحصائية عند مستوى

قام صالح والمبيضين (2013) بدر اسة هدفت الى التعرف على أثر القيادة التبادلية والتحويلية في تجسيد الاهداف الاستر اتيجية

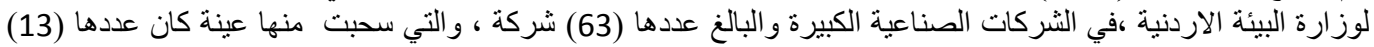

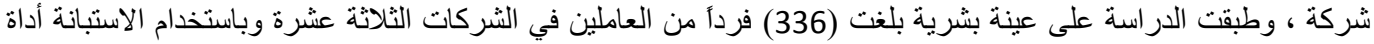

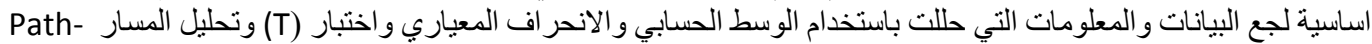

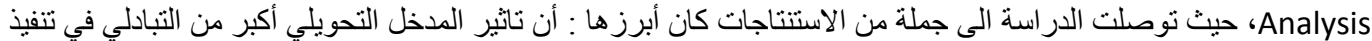

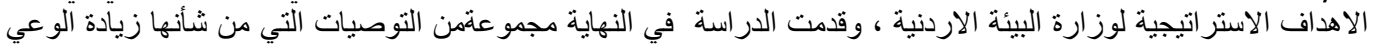

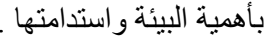

دراسة العوائد (2001) ، بعنوان " تقويم أداء القيادات الإدارية في مديريات التربية والتعليم في سلطنة عمان في ضوء العيات المهمات

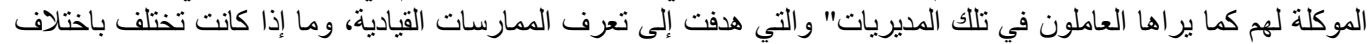

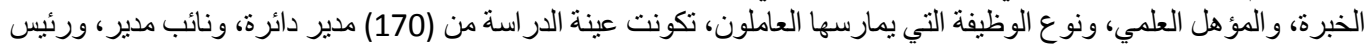

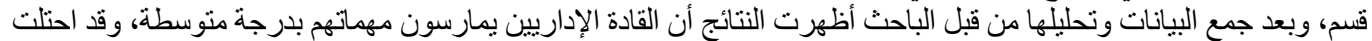

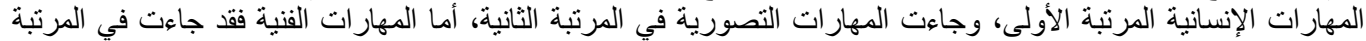

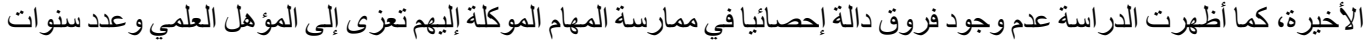

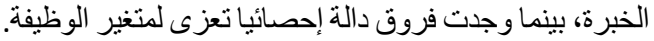

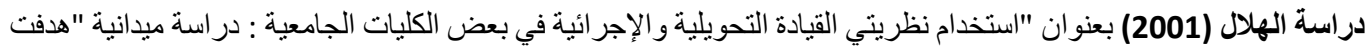

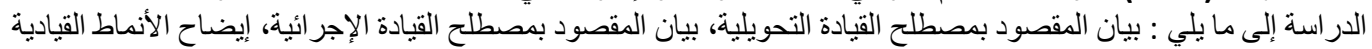

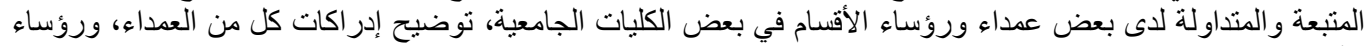

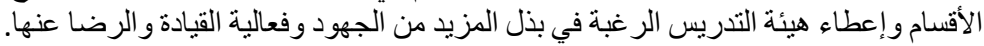

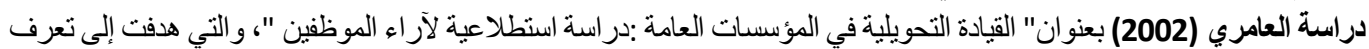

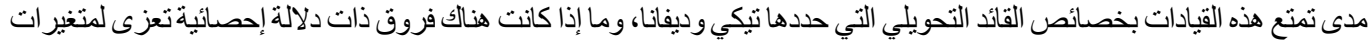

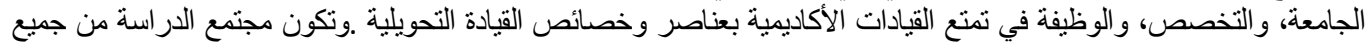

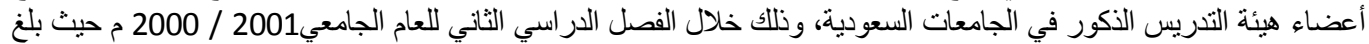

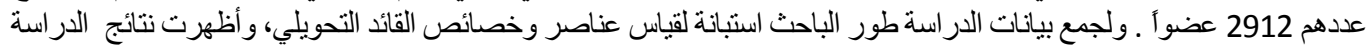

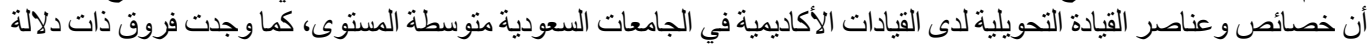

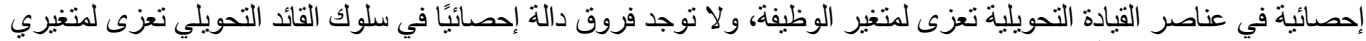

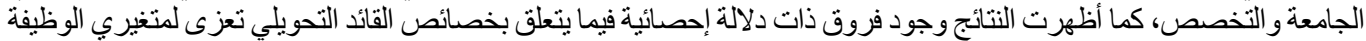

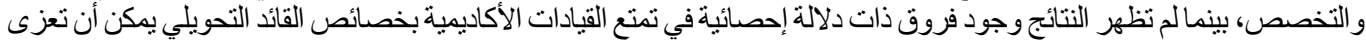
المتغير الجامعة.

قام عماد الدين (2004) بدراسة بعنوان قيادة التغيير هدف البحث إلى التعريف بقيادة التغيير، ومجالات عمل قيادة التياد التغيير

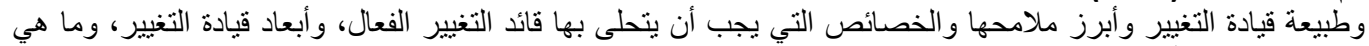
معوقات التغيير و أبرز التحديات التي تقاوم التغيير ثم خلصت الدر اسة بوضع مقترحات تضمن نجاح التغيير وتساعد على التغلب التبان على مقاو مة التغيير.

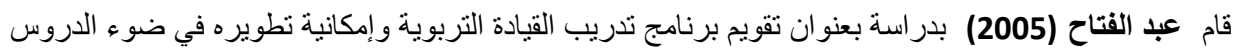

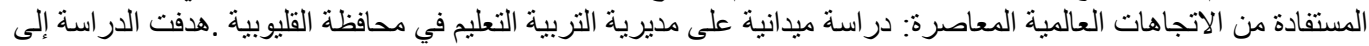

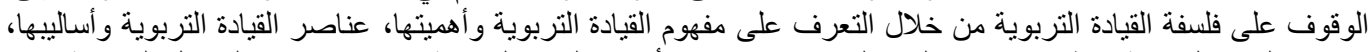

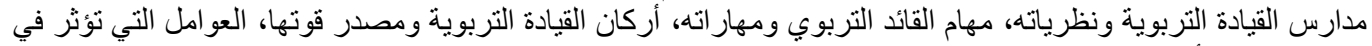

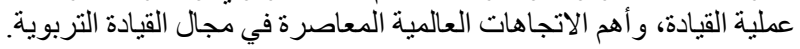

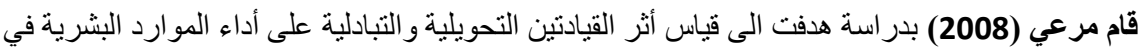

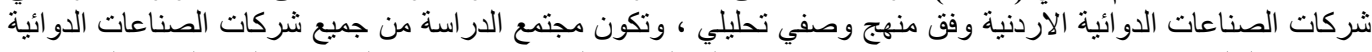

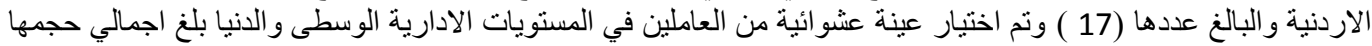

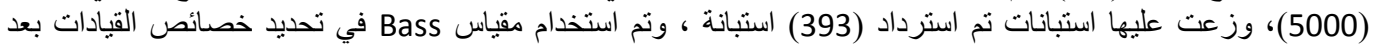

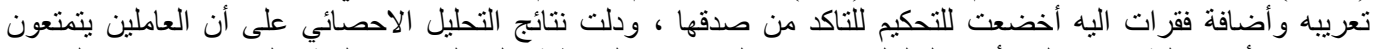

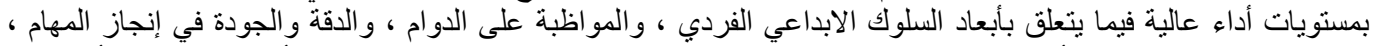

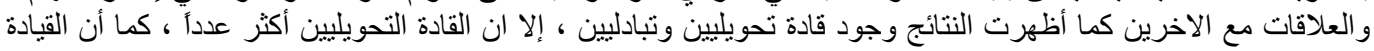


التحويلية توثر ايجابأ السلوك الابداعي الفردي ، و المواظبة على الدوام ، و الدقة والجودة في إنجاز المهام ، والعلاقات مع الاخرين.

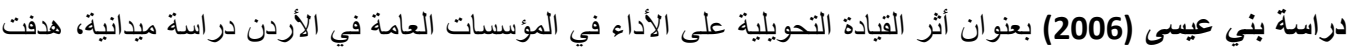

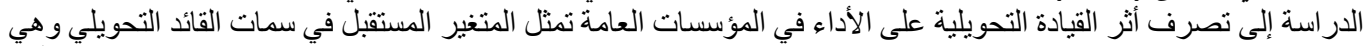

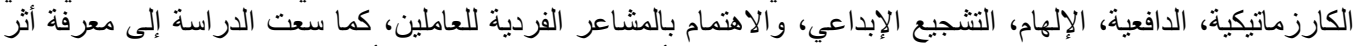

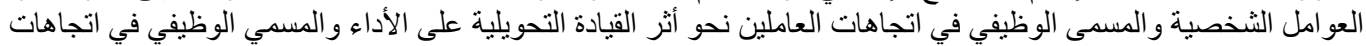

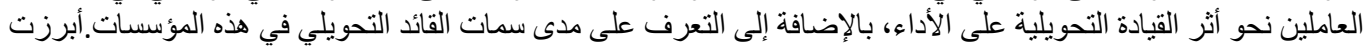
النتائج ما يلي:

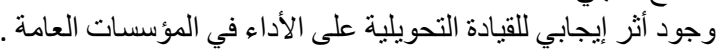

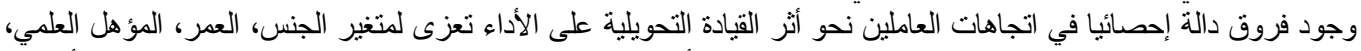

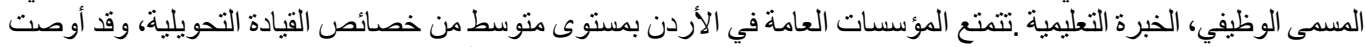

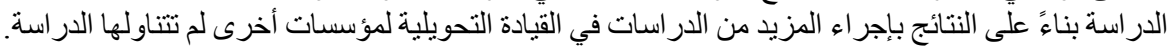

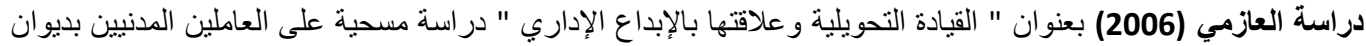

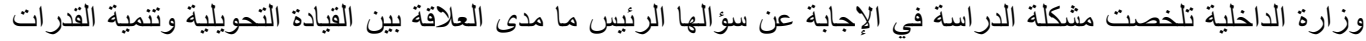

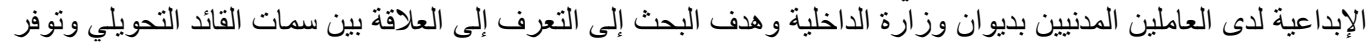

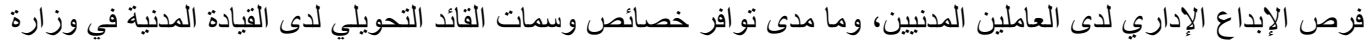

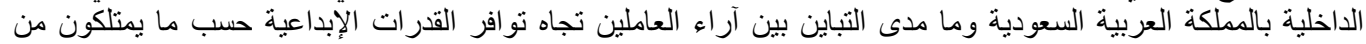

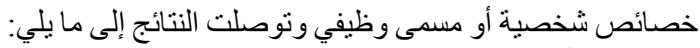

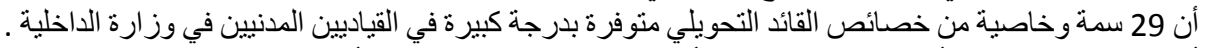

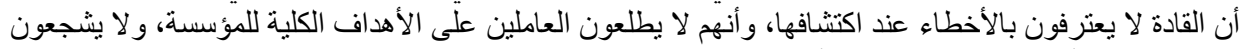

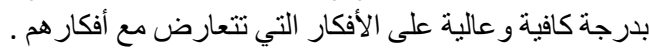
وجود علاقة طردية بين امتلاك القائد لسمات وخصار الفيائص القائد التحويلي وبين امتلاك المرؤوسين لمهار ات وقدرات

وجود فروق إحصائيا في امتلاك خصائص وسمات القائد التحويلي تعزى إلى المؤ هل العلمي و الخبرة.

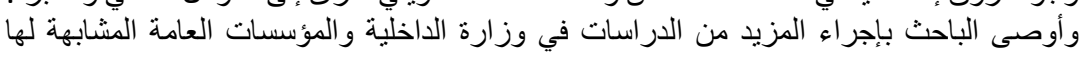

ثانيا : الاراسات الأجنبية - دراسة زاقناك (Sagnak, 2010) هدفت هذه الدر اسة إلى معرفة العلاقة بين القيادة التحويلية والمناخ الأخلاقي في المدارس.

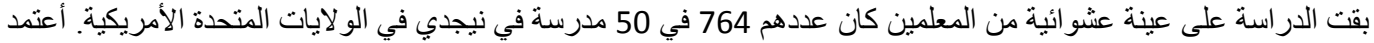

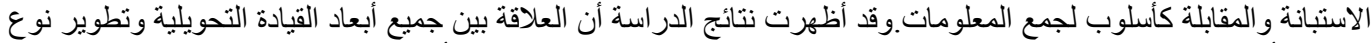

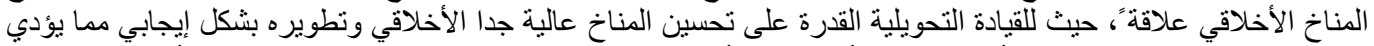

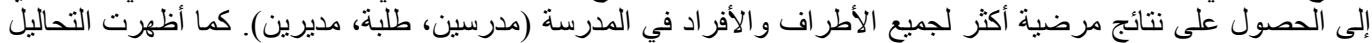

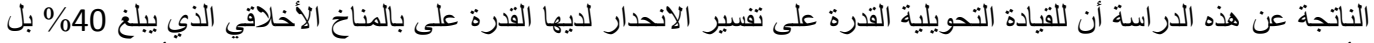

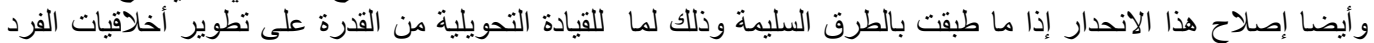
وظهار ا أفضل ما يملك من سمات وضات وصفات. - قام (Edwards \& Gill, 2011) بدر اسة هدفت الى التعرف على مدئ مدى ممارسة القيادة التحويلية والتبادلية و عدم التدخل في

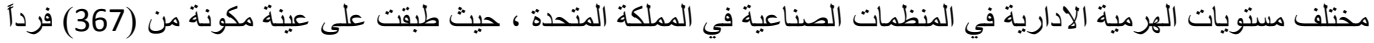

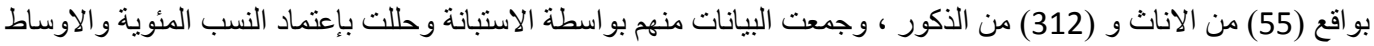

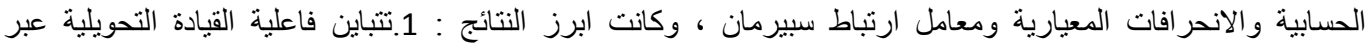

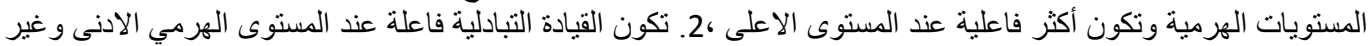
فاعلة عند المستوى الاعلى . المعند

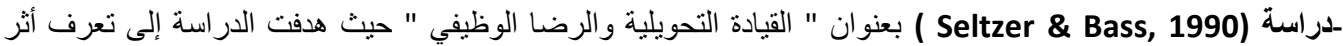

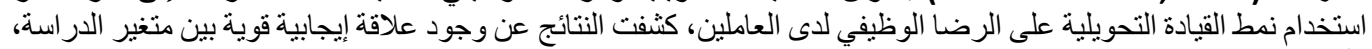

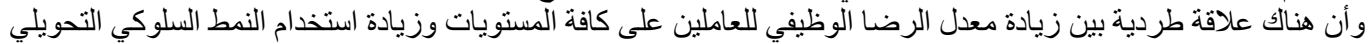
من القادة، حيث أظهرت النتائج أن التأثثر كان ولن واضحأ ومميز آل لاى أفر اد العينة. 
ـ ـ دراسة (Zalezink, 1990) بعنوان " القيادة التحويلية و الثقافة التتظيمية " حيث سعت الباحثة إلى معرفة أثر القيادة التحويلية

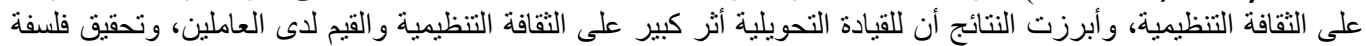

المؤسسة و أهدافها).

ـ دراسة (Howell \& Avolio, 1993) بعنوان " نأثير القيادة التحويلية على الأداء التنظيمي للمنظمة " سعت الدراسة لبيان التيان

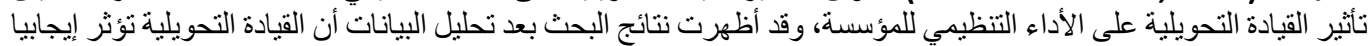

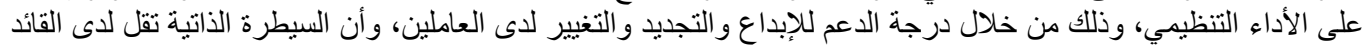

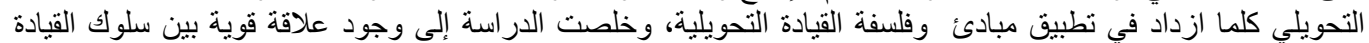
التحويلية في المؤسسة وتنطوير الأداء التنظيمي للمؤسية.

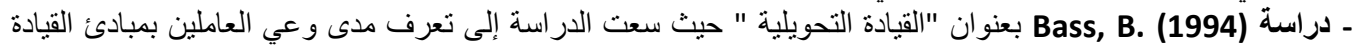

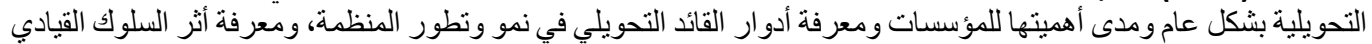

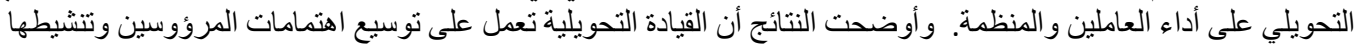

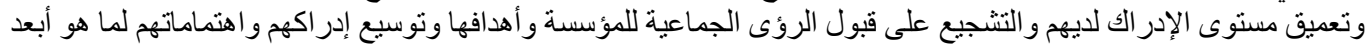

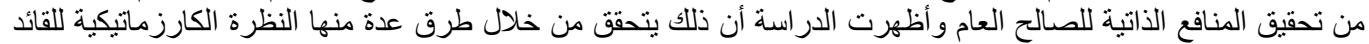

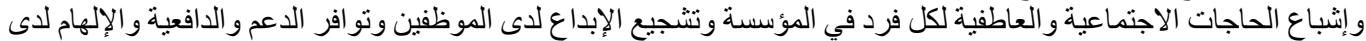

- دراسة (Barling et al., 1996 ) توصلت الدراسة إلى وجود علاقة ارتباطية عالية بين الجهود الإضافية للعاملين و الرضا

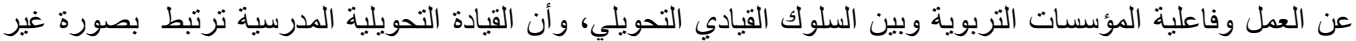

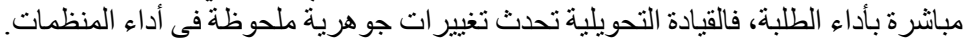

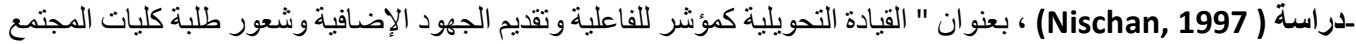

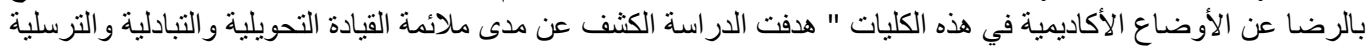

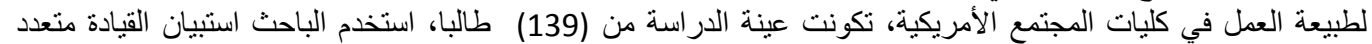

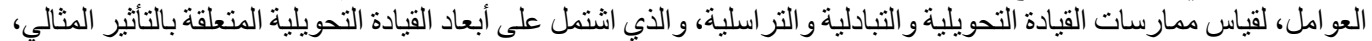

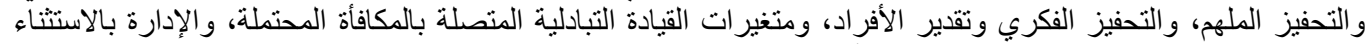

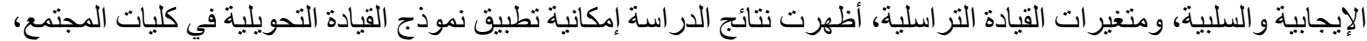

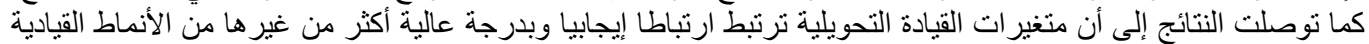

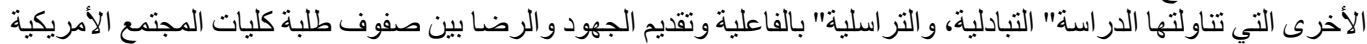

.(Nischan:1997)

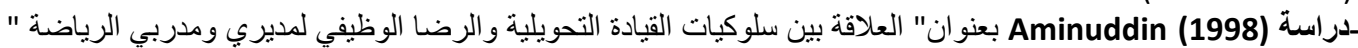

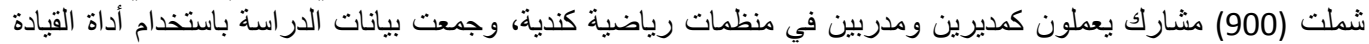

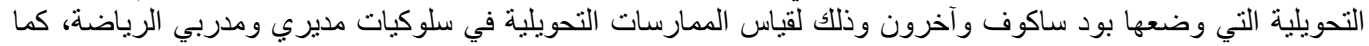

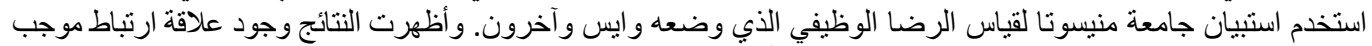

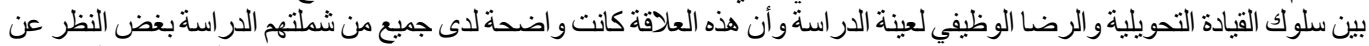

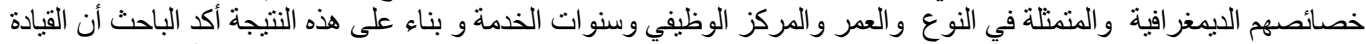

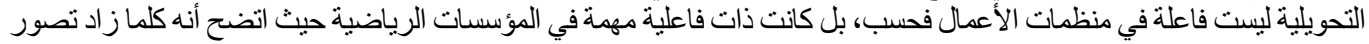

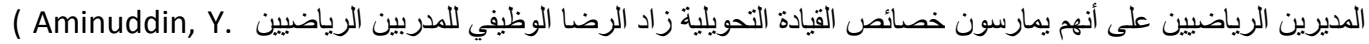

- دراسة ( Pillia et al., 1999 (بعنوان " الإدراك المعتدل والثقة للقائد التحويلي " هدفت الدراسة إلى معرفة أثر القيادة

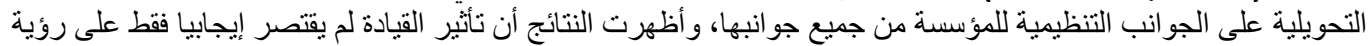

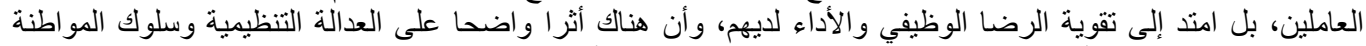

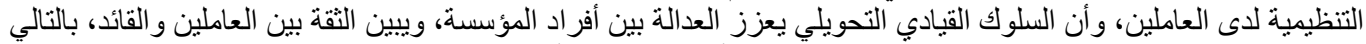

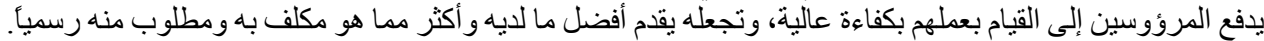

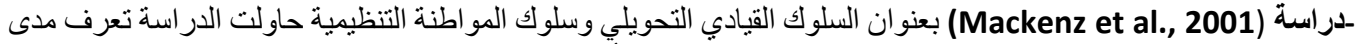

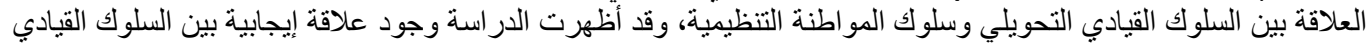

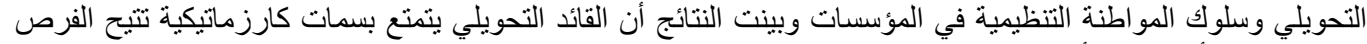

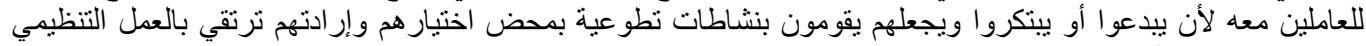
وتساهم في تحسين أداء المنظمة بشكل عام. 
التعليق على الار اسات السابقة ذات الصلة:

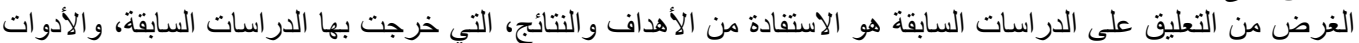

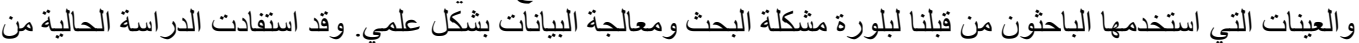

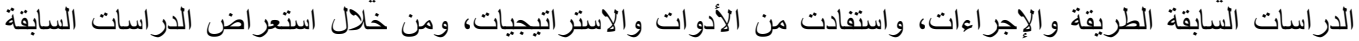

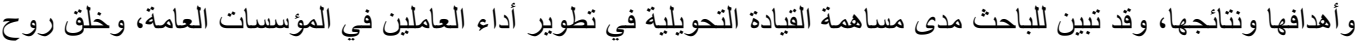

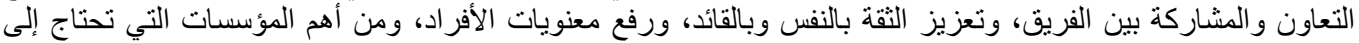

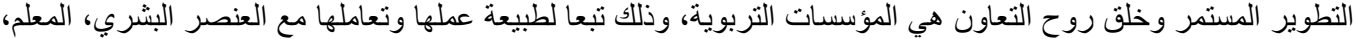

مشكلة البحث:

تباينت التفسير ات المرتبطة بأداء المؤسسات التربوية وفاعليتها، غير أنها لم تخرج الته عن مجمو عة العو امل الديمغر افية و التنظيمية

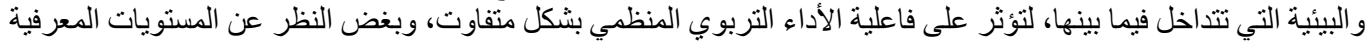

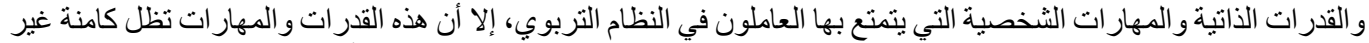

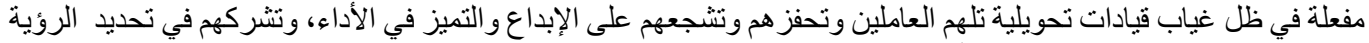

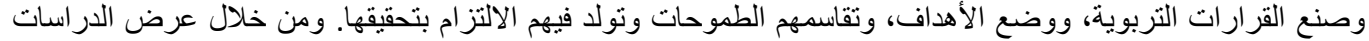

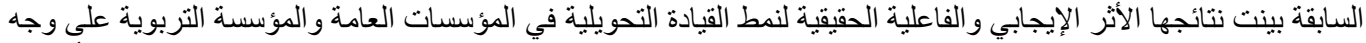

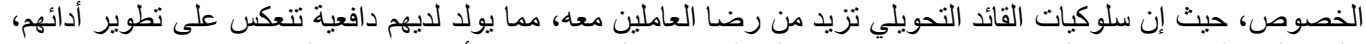

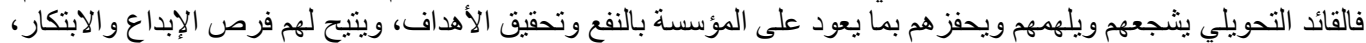

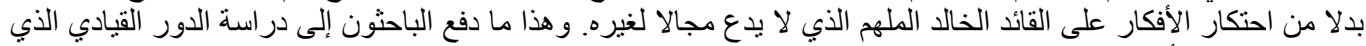

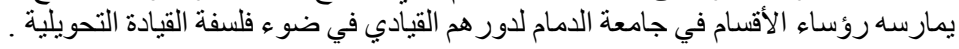

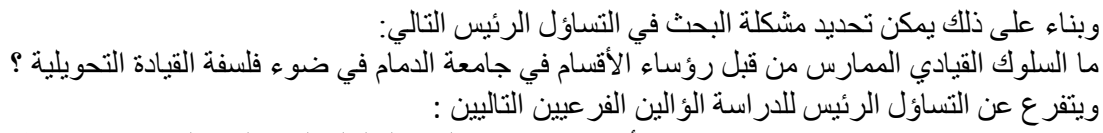
1. 2. وجهة نظر أعضاء هيئة التدريس تعزى للمتغير ات التالية : الجنس، الخبرة، والئة والدرجة العلمية؟

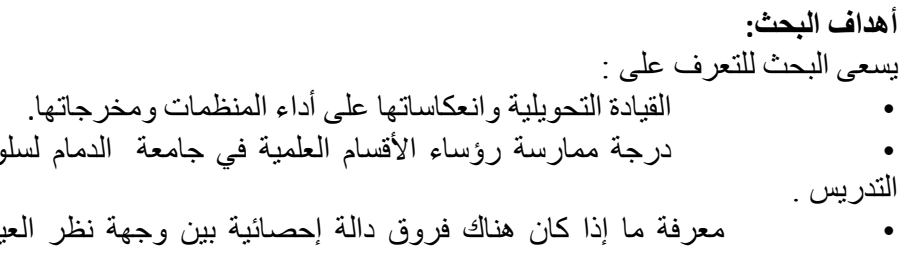
• • الدرجة العلمية. معرفة ما إذا كان هنالك فروق دالة إحصائية بين وجهة نظر العينة تعزى إلى متغيرات الجنس، الخبرة ،

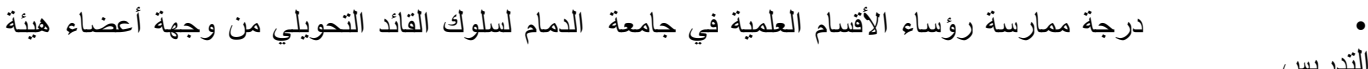

أهمية البحث:

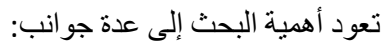

الأول : الجانب النظري حيث لا يز ال جانب القيادة بحاجة إلى المزيد من الدر اسات و الأبحاث في المملكة العربية السعودية.

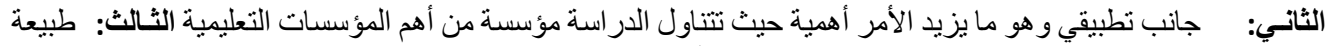

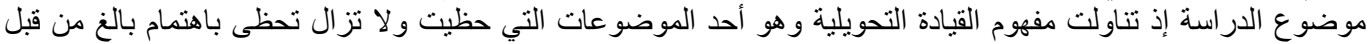
الباحثين و المطورين في مجال التربية و الادارة . الرابع: رؤية الباحثون بأن المؤسسات التربوية بحاجة إلى أساليب قيادية متقدمة وناجعة تسعى إلى الوقوف في وجه التحديات العالمية و العصرية التي تو اجهها ـ. 


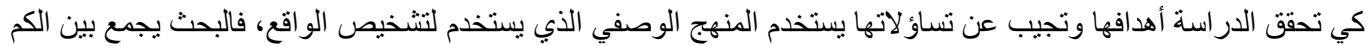

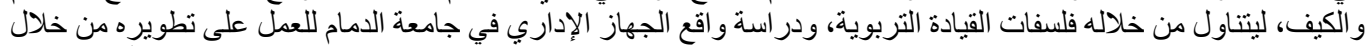

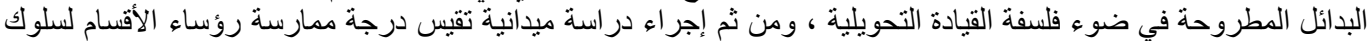
القائد التحويلي في جامعة الدمام.

استخدم الباحثون أداة الاستبانة حبث وز عت على عبنة من العاملين من أعضاء هيئة الترديس في أقسام جامعة الدمام لمعرفة درجة ممارسة رؤساء الأقسام لسلوك القائد التحويلي في جامعة عندة الدمام.

يقتصر البحثث على أعضاء هيئة التدريس في جامعة الدمام (المركز)، للعام الدراسي 1433/ 1434، 2012 لحئ 2013.

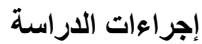
أولا: مجتمع وعينة الاراسة : الراسية

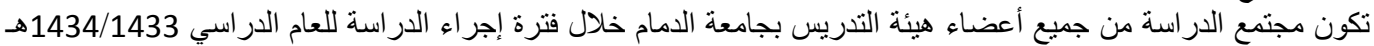

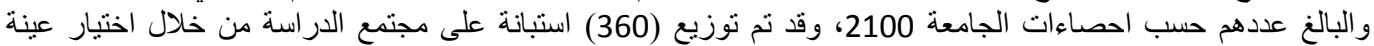

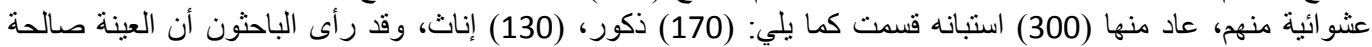

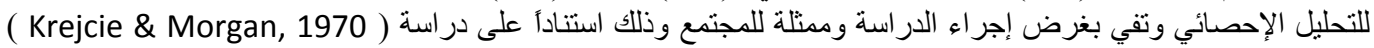

لتحديد حجم عينة الدراسة.

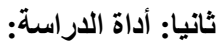

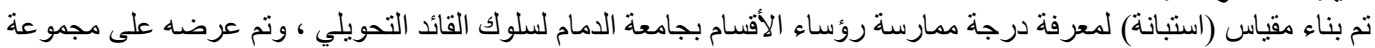

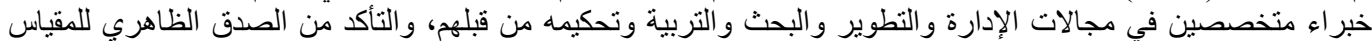
بتعديله وفق آراء وتوصيات المحكمين، ومن ثم اعتماد الاستبانة بصورتها ولتها النهائية.

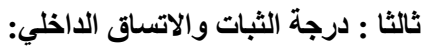

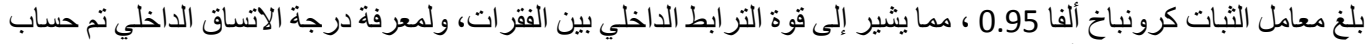

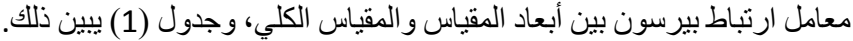

\begin{tabular}{|c|c|}
\hline معامل ارتباط بيرسون & 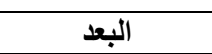 \\
\hline 0.91 & التأثثير المثالي \\
\hline 0.90 & الاستثارة الفكرية \\
\hline 0.93 & الاعتبارية الفردية \\
\hline 0.88 & 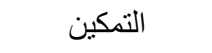 \\
\hline 0.94 & التغيير \\
\hline
\end{tabular}

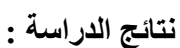

استخدم الباحثون مقياس ليكرت الخماسي وفقا للتقديرات : بدرجة عالية جدا (5) ، بدرجة عالية (4) ، بدرجة متوسطة (3) ،

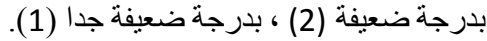
وجاء تفسير النتائج وفقا للنسب ، وللمتوسط الحسابي وفق التقديرات التالية : 
Journal of Social Sciences (COES\&RJ-JSS), 5(1), pp.56-79

\begin{tabular}{|c|c|}
\hline مستوى الاستجابة (الممارسة) & مدى المتوسط \\
\hline ضعيفة جدا & $1.80-1$ \\
\hline ضعيفة & $2.60-1.81$ \\
\hline متوسطة & $3.40-2.61$ \\
\hline عالية & $4.20-3.41$ \\
\hline عالية جدا & $5-4.21$ \\
\hline
\end{tabular}

وفيما يلي عرضا لنتائج الدراسة : النتائج المتعلقة بالسؤال الأول: نص السؤل التوال على ما يلي " ما درجة ممارسة رؤساء الأقسام في جامعة الدمام لسلوك القائد

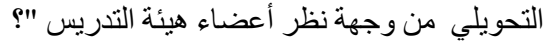

جدول (3): المتوسطات الحسابية والانحر افات المعيارية لدرجة ممارسة رؤساء الأقسام في جامعة الدمام لسلوك القائد التحويلي

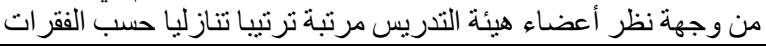

\begin{tabular}{|c|c|c|c|}
\hline 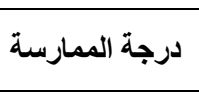 & المعياري & الحستوسي & 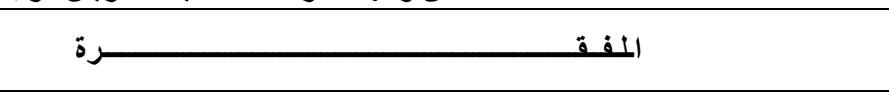 \\
\hline 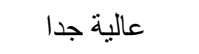 & 1.0 & 4.94 & يقدم تصور ا شاملا للعمل تاركا المساحة الأكبر للعاملين ليقومو ا بالتنفيذ \\
\hline 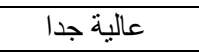 & 0.95 & 4.92 & يثير في العاملين روح الحماس تجاه العمل التربوي \\
\hline 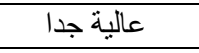 & 4.06 & 4.24 & يؤمن أن التغيير مرحلة تقود إلى الأفضل \\
\hline عالية & 0.91 & 4.2 & بستجيب بفاعلية لمبادر ات العاملين التطويرية \\
\hline عالية & 0.90 & 4.2 & يحدد بدقة مهام وواجبات العاملين لضمان إحداث عملية التغيير \\
\hline عالية & 0.90 & 4.2 & يوضح للعاملين معه أهمية وجوده في القسم \\
\hline عالية & 0.97 & 4.14 & يمارس عملية تفويض الصلاحيات وفق أسس علمية \\
\hline عالية & 0.86 & 4.1 & يحظى بشخصية محببة لاى العاملين معه \\
\hline عالية & 0.90 & 4.14 & يحرص على ضرورة تكافؤ السلطة مع المسؤولية عند تفويضه لبعض الصلاحيات \\
\hline عالية & 0.96 & 4.10 & يترجم رؤاه إلى حقائق على أرض الو اقع ب \\
\hline عالية & 0.87 & 4.1 & يعطي أولوية لبناء مجمو عة من القيم المشتركة داخل المؤسسة \\
\hline عالية & 0.83 & 4.1 & يشجع على العمل بروح الفريق الواحد ئ \\
\hline عالية & 0.91 & 4.1 & يسعى إلى رفع مستوى اهتمام العاملين بالتطوير التربوي \\
\hline عالية & 1.07 & 4.02 & يشجع العاملين على تحمل المسؤولية \\
\hline عالية & 0.95 & 4.01 & يتفهم وير اعي مشاعر العاملين معه \\
\hline عالية & 0.92 & 4.01 & يحرص على إثباع الحاجات الاجتماعية للعاملين \\
\hline عالية & 0.93 & 4.1 & يعمل على إيجاد حس جماعي بالمهام التربوية \\
\hline 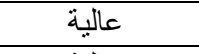 & 0.94 & 4.0 & يتعامل مع القضايا التربوية على أسس علمبة ومنظمة \\
\hline عالية & 0.97 & 4.1 & تعزز قيادته للقسم ثقة العاملين بالقيادة \\
\hline عالية & 0.97 & 4.0 & ير غب العاملين في الاستمر ار بالقسم رغم إناحة فرص الانتقال إلى أقسام أخرى \\
\hline عالية & 0.99 & 4.2 & يتفرد بأساليب قيادية في تعامله الإداري يميزه عن غيره \\
\hline عالية & 1.0 & 4.2 & يهتم بالمصلحة العامة ويقدمها على المصلحة الثخصية \\
\hline عالية & 1.0 & 4.1 & يوفر للعاملين مناخا يحببهم بالاستمر ار تحت قيادته \\
\hline عالية & 1.0 & 4.2 & يعمل على تفعيل إمكانيات وقدارت العاملين \\
\hline عالية & 0.87 & 4.0 & يهتم بتحفيز العاملين معه لتحقيق رؤية الجامعة \\
\hline
\end{tabular}


The degree of heads of departments at the University....

\begin{tabular}{|c|c|c|c|}
\hline عالية & 0.87 & 4.1 & برسخ مفهوم المشاركة بين العاملين بصورة مستمرة \\
\hline عالية & 0.86 & 4.2 & يزود العاملين بالطرق الجديدة للتعامل مع مشكلات القسم \\
\hline عالية & 0.90 & 4.1 & يحرص على توضيح الأهداف التربوية للعاملين معهد \\
\hline عالية & 1.08 & 4.0 & يفوض بعض الصلاحيات للعاملين معهه \\
\hline عالية & 1.0 & 4.1 & يعبر عن تقديره وامتنانه للعاملين و المتميزين في أداء الو اجبات المهنية \\
\hline عالية & 0.96 & 4.2 & يحرص على التزام العاملين بعملية التغيير أثناء تنففيذها \\
\hline عالية & 0.89 & 3.98 & 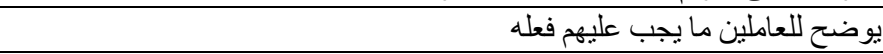 \\
\hline عالية & 1.0 & 3.97 & يحترم القناعات التربوية لدى العاملين معه \\
\hline عالية & 0.99 & 3.99 & يرسخ المفاهيم التي تؤدي إلى نجاح عملية التغيير \\
\hline عالية & 0.93 & 3.98 & يشجع العاملين على تحقيق أكثر مما يتوقعون تحقيقه من أنفسهح \\
\hline عالية & 0.97 & 3.97 & يساعد العاملين على إيجاد معنى للعمل التربوي \\
\hline 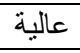 & 0.96 & 3.96 & يحرص على إيصال رؤيته التربوية للعاملين معه \\
\hline عالية & 1.0 & 3.98 & يحرص على إثباع الحاجات النفسية للعاملين \\
\hline عالية & 0.97 & 3.98 & قادر على إقناع العاملين معه بضرورة التغيير \\
\hline عالية & 1.01 & 3.96 & يحرص على شُعور كل عامل معه بأهمية وجوده في القسم \\
\hline عالية & 1.0 & 3.95 & يضع للعاملين معايير إنجاز قابلة للتحقيق \\
\hline عالية & 1.0 & 3.96 & يعمل على تكييف سلوك العاملين بما يناسب مع برنامج التغيير \\
\hline عالية & 0.94 & 3.97 & يحرص على إخر اج أقصى ما لدى العاملين من أداء \\
\hline عالية & 0.90 & 3.98 & يحفز العاملين على مناقتشة الأفكار الجديدة \\
\hline عالية & 1.0 & 3.96 & يشجع العاملين على اكتثاف حلول إبداعية للمشكلات التي تو اجههم \\
\hline عالية & 1.0 & 3.97 & يدعم كل فرد للقيام بمهامه الموكله إليه \\
\hline عالية & 1.02 & 3.97 & يأخذ بعين الاعتبار المهار ات الإدارية لمن يفوض لهم الصلاحيات \\
\hline عالية & 0.91 & 3.95 & يمتلك القدرة على تحديد رسالة المؤسسة \\
\hline عالية & 1.02 & 3.98 & يؤمن أن للمدير دورا فاعلا في إحداث التغيير الإيجابي \\
\hline عالية & 1.0 & 3.97 & يحترم إنسانية العاملين معه \\
\hline عالية & 1.04 & 3.96 & قادر على اختبار النموذج الملائم لتغيير المؤسسة \\
\hline عالية & 0.99 & 3.94 & يحرص على مشاركة العاملين في عملية التغيير \\
\hline عالية & 0.95 & 3.92 & يحرص على أن تتطابق ممارسته للرؤى التي يمتلكها \\
\hline عالية & 1.0 & 3.93 & يتعامل مع كل العاملين بالطريقة المناسبة \\
\hline عالية & 0.97 & 3.92 & يدرك أن هناك مبررات قوية لتغيير الأوضاع التربوية \\
\hline عالية & 0.94 & 3.91 & يشعر بالارتياح عند تحقيق معدلات أداء عالية \\
\hline عالية & 0.93 & 3.9 & يجسد قدوة ونمو ذجا يحتذى في ممارساته الإدارية \\
\hline عالية & 0.93 & 3.9 & يتميز بقدرته على استشر اف المستقبل \\
\hline عالية & 1.0 & 3.9 & يثق بإمكانيات العاملين معه \\
\hline عالية & 1.0 & 3.9 & يجسد النجاح بالمؤسسة مما يدفع العاملين إلى تحقيق المزيد من الإنجاز \\
\hline عالية & 1.05 & 3.87 & يناقش العاملين في متطلبات إنجاز أدو ارهم الوظيفية \\
\hline عالية & 1.0 & 3.87 & يثري الأهداف الجديدة في قسمه \\
\hline عالية & 1.10 & 3.86 & يعمل على إنباع حاجات المرؤوسين لضمان التزامهم بعملية التغيير \\
\hline عالية & 1.0 & 3.86 & ينصت لأر اء العاملين معه باهتمام \\
\hline عالية & 1.8 & 3.85 & يعمل على تزويد القسم بالوسائل و الأدو ات اللازمة لإتمام عملية التغيير و استمر اره \\
\hline عالية & 1.11 & 3.85 & يوفر مناخاو استر اتيجيات مناسبة لإتمام عملية التغيير و استمر اره \\
\hline عالية & 1.0 & 3.83 & يبدي اهتماما شخصيا لجميع العاملين معهد \\
\hline عالية & 1.06 & 3.82 & يبدي تعاونه بغض النظر عن حجم الجهود المبذولة من العاملين \\
\hline
\end{tabular}


Journal of Social Sciences (COES\&RJ-JSS), 5(1), pp.56-79

\begin{tabular}{|c|c|c|c|}
\hline عالية & 1.0 & 3.80 & يشجع العاملين على تحقيق التميز في الأداء \\
\hline عالية & 0.98 & 3.82 & يشجع العاملين على المشاركة في صنع القرار التربوي \\
\hline عالية & 1.07 & 3.79 & يمتلك رؤى جديدة تحقق أهداف المؤسسة \\
\hline عالية & 0.99 & 3.76 & يضع للعاملين معايير إنجاز قابلة للتنفيذ \\
\hline متوسطة & 1.12 & 3.40 & قادر على تحديد أهداف المؤسسة \\
\hline متوسطة & 0.96 & 3.35 & يحترم وجهات النظر المتبادلة عند تعامله مع القضايا التربوية \\
\hline متوسطة & 0.94 & 3.16 & قادر على تكييف المؤسسة مع عملية التغيير \\
\hline
\end{tabular}

يتضح من جدول (3) أن المتوسط الحسابي لجميع الفقرات ترواح بين ( 3.16 - 4.94) من 5 و وتمثل كل المنتوسطات درجة

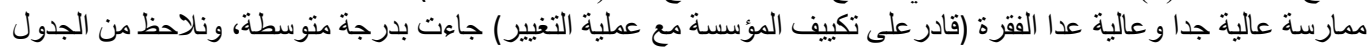
أيضا أن أعلى الفقر ات ممارسة كانت:

يقدم تصور ا شاملا للعمل تاركا المساحة الأكبر للعاملين ليقو مو ا بالتتفيذ. يثير في العاملين روح الحماس تجاه العيل العمل التربوي.

يؤمن أن التغيير مرحلة تقود إلى الأفضل

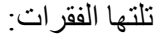

يستجيب بفاعلية لمبادرات العاملين التطويرية

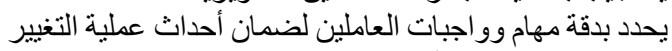

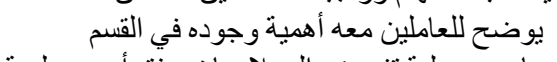

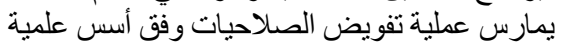

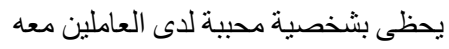

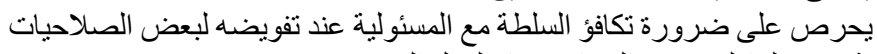

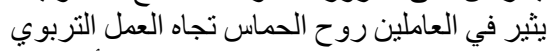

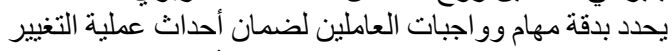

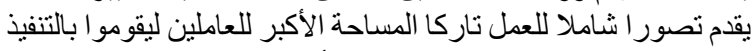

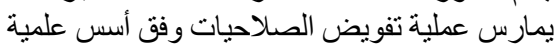

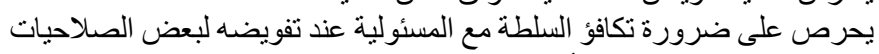

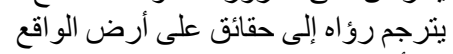
و وأدناها ممارسة كانت:

يو فر مناخاو استر اتيجيات مناسبة لإنمام معام عملية التغيير واستمر اره

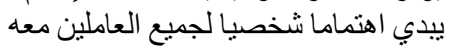

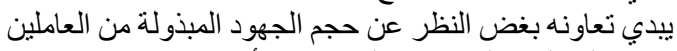
يشجع العاملين على تحقيق التميز في الأداء

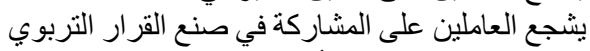
يمتلاك رؤى جديدة تحقق أهداف المؤسيسة

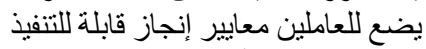
قادر على تحديد أهداف المؤسيسة

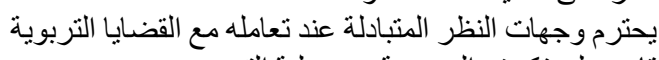

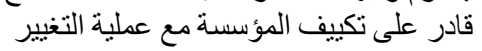

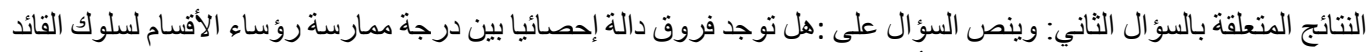

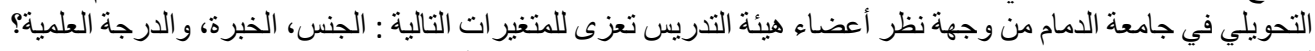

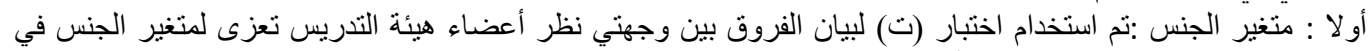

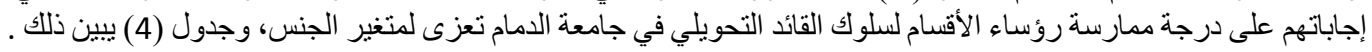


The degree of heads of departments at the University....

\begin{tabular}{|c|c|c|c|c|c|c|c|}
\hline الاحصائية & قيمة & الحرجية & المعياري & المعياري & الحسابي & العينة & الجنس \\
\hline \multirow{2}{*}{0.246} & \multirow{2}{*}{8.80} & 159 & 4.67 & 55.11 & 2.92 & 100 & ذكر \\
\hline & & 24.60 & 16.22 & 76.11 & 2.56 & 40 & أنثى \\
\hline
\end{tabular}

يتضح من جدول (4) أنه نوجد فروق ذات دلالة إحصائية عند مستوى الدلالة (0.05) ، بين متوسطات درجات أفراد عينة

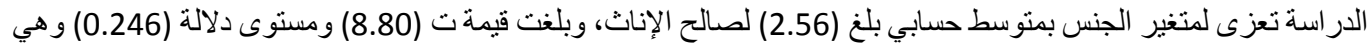
قيمة دالة إحصائيا.

ثنانيا : متغير الخبرة : تم استخدام اختبار تحليل التباين الأحادي ANOVA لبيان الفروق بين وجهة نظر أعضاء هيئة التدريس

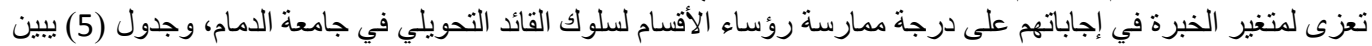

جدول (5) :اختبار تحليل التباين الأحادي ANOVA لبيان الفروق بين وجهتي نظر أعضاء هيئة التدريس تعزى لمتغير الخبرة

\begin{tabular}{|c|c|c|c|c|c|}
\hline مستوى الدلالة & قيمة (ف) & متوسط المربعات & درجة الحرية & مجموع المربعات & مصدر التباين \\
\hline \multirow{3}{*}{0.512} & \multirow{3}{*}{0.662} & 2260.606 & 2 & 452.213 & بين المجمو عات \\
\hline & & 3400.151 & 158 & 537223.818 & داخل المجمو عات \\
\hline & & & 160 & - & الكلي \\
\hline
\end{tabular}

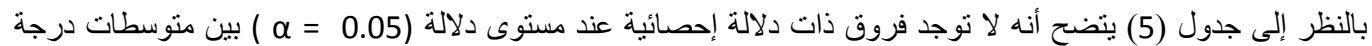

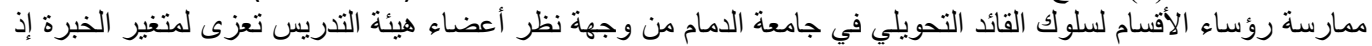
بلغت قيمة ف (0.662) وبمسنوى دلالة بلغ (0.512) و هي غير دالة النيأل إحصائيا.

ثالثا : متغير الدرجة العلمية :تم استخدام اختبار تحليل التباين الأحادي ANOVA لبيان الفروق بين وجهة نظر أعضاء هيئة

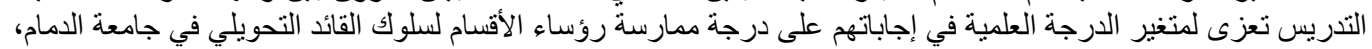
وجدول (6) ييين ذلك.

جدول (6) :اختبار تحليل التباين الأحادي ANOVA لبيان الفروق بين وجهة نظر أعضاء هيئة التدريس تعزى لمتغير الدرجة

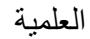

\begin{tabular}{|c|c|c|c|c|c|}
\hline مستوى الدلالة & قيمة (ف) & متوسط المربعات & درجة الحرية & مجموع المربعات & مصدر التباين \\
\hline \multirow{3}{*}{0.886} & \multirow{3}{*}{0.180} & 2260.606 & 2 & 811.053 & بين المجمو عات \\
\hline & & 3400.151 & 158 & 540933.979 & داخل المجمو عات \\
\hline & & & 160 & - & الكلي \\
\hline
\end{tabular}

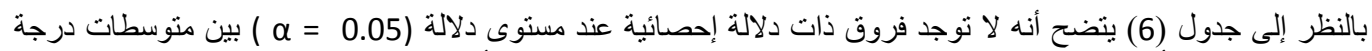

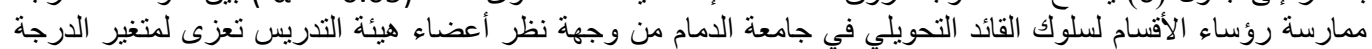

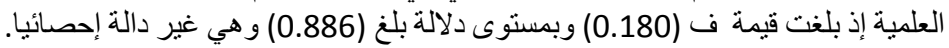


هدفت الدر اسة إلى تعرف درجة التُة ممارسة رؤساء الأقسام لسلوك القائد التحويلي في جامعة الدمام من وجهة نظر أعضاء هيئة

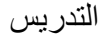
وقد استخدم الباحثون أداة عبارة عن استبانة تضمنت (75) فقرة ذات علاقة بموضوع الدر اسة، موزعة على خمسة أبعاد، وبعد

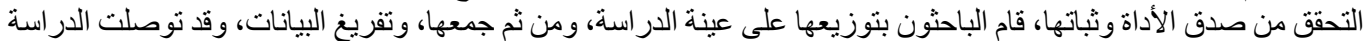

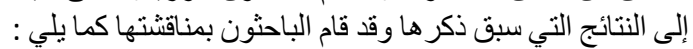

\section{مناقثة النتائج المتعلقة بالسؤال الأول:}

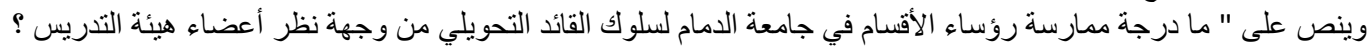

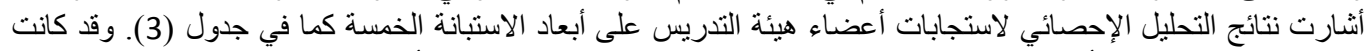

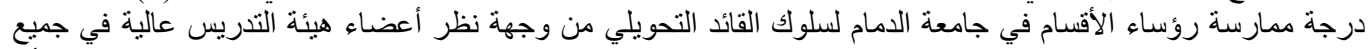

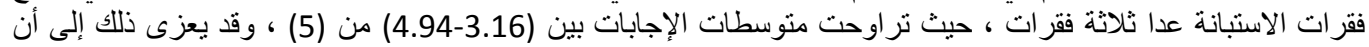

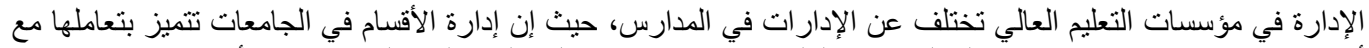

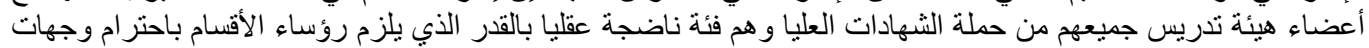

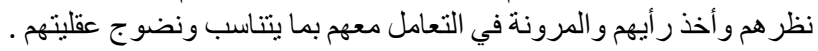

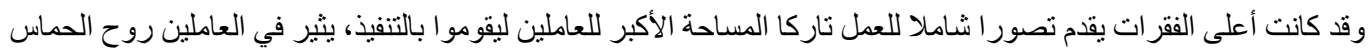

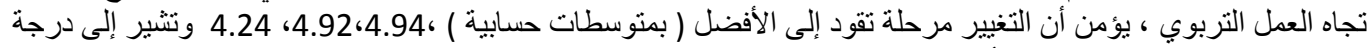

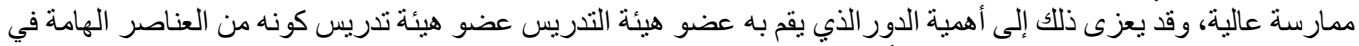

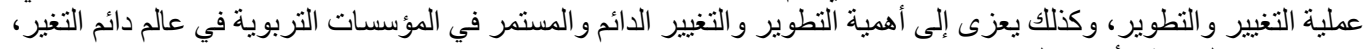

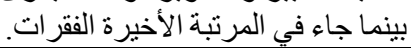

\begin{tabular}{|c|c|c|c|}
\hline متوسطة & 1.12 & 3.40 & قادر على تحديد أهداف المؤسسة \\
\hline متوسطة & 0.96 & 3.35 & يحترم وجهات النظر المتبادلة عند تعامله مع القضايا التربوية \\
\hline متوسطة & 0.94 & 3.16 & قادر على تكييف المؤسسة مع عملية التغيير \\
\hline
\end{tabular}

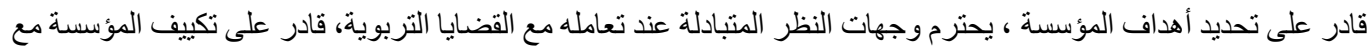

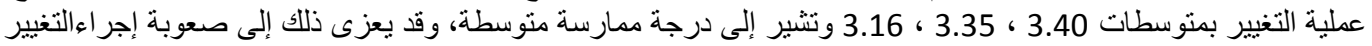

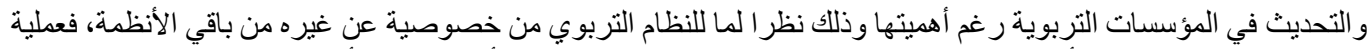

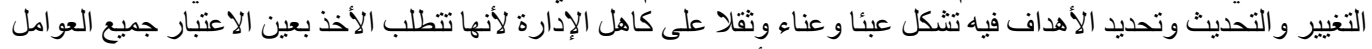

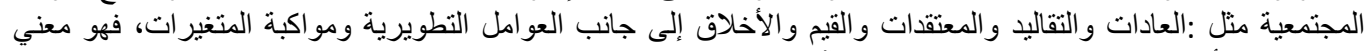

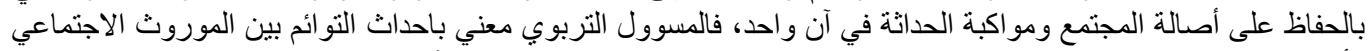

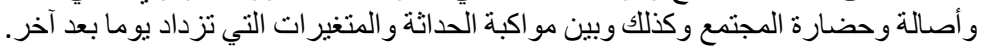

مناقثة النتائج المتعلقة بالسؤال الثاني: وينص على :هل توجد فروق دالة إحصائيا بين درجة ممارسة رؤساء الأقسام في

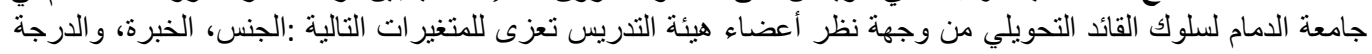

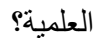
أولا :متغير الجنس :أشارت نتائج التحليل الإحصائي لاستجابات أعضاء هيئة التدريس حسب اختبار (ت) على أبعاد الاستبانة

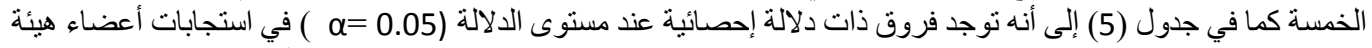

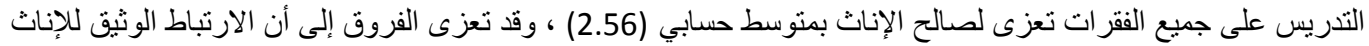

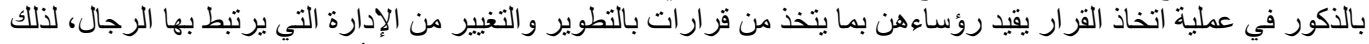

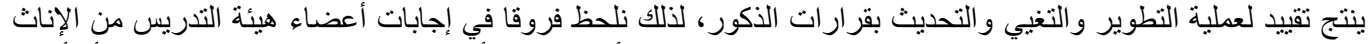

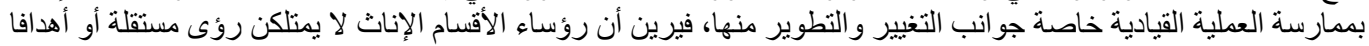

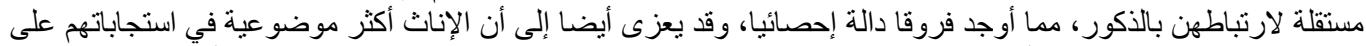

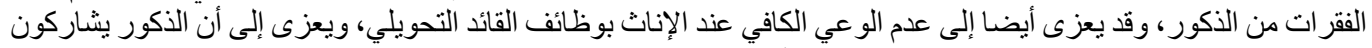

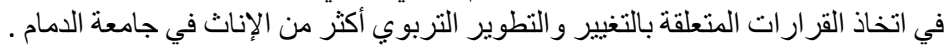




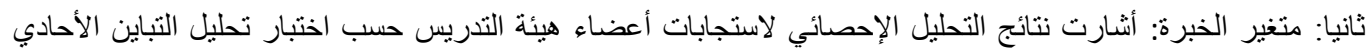
(ANOVA )

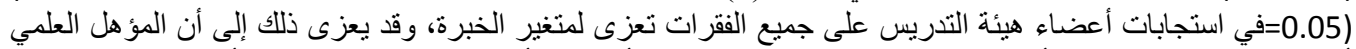

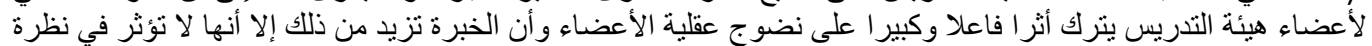

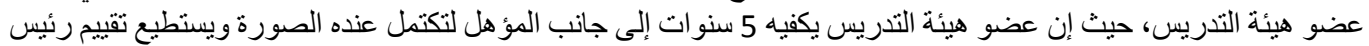

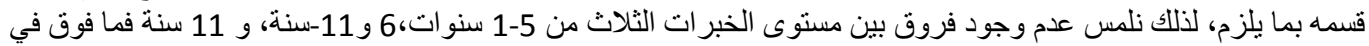

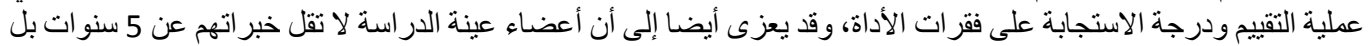

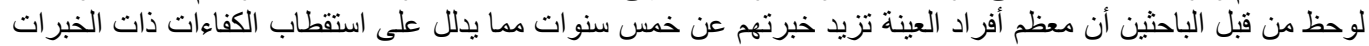
العالية من قبل الجامعة. ثالثا :متغير الدرجة العلمية :أشارت نتائج التحليل الإحصائي لاستجابات أعضاء هيئة التدريس حسب اختبات التبار تحليل التباين

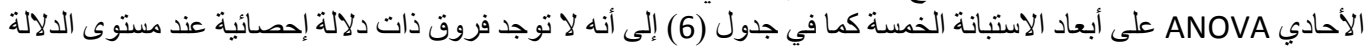

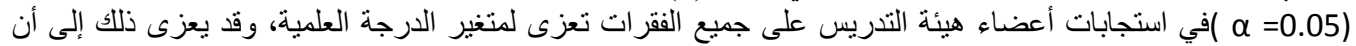

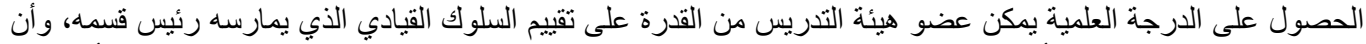

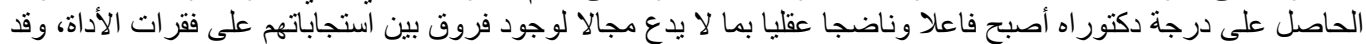

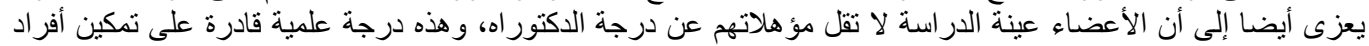
العينة من فهم السلوك القيادي وتقييمه.

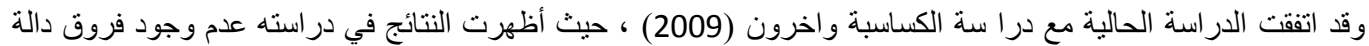

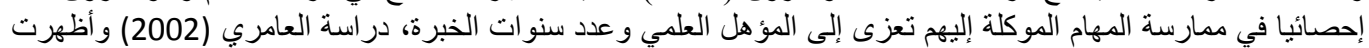

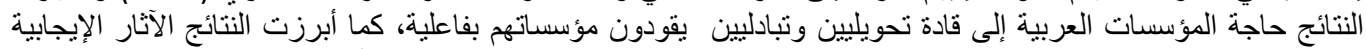

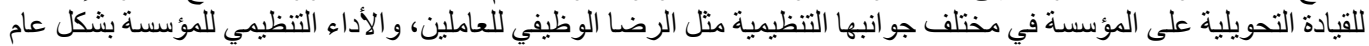

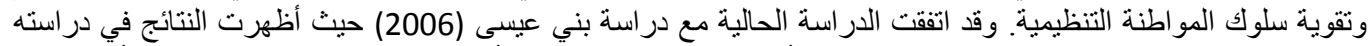

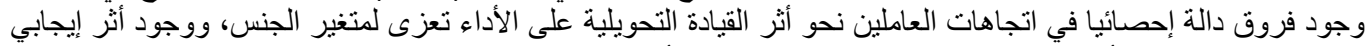

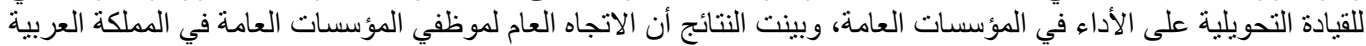

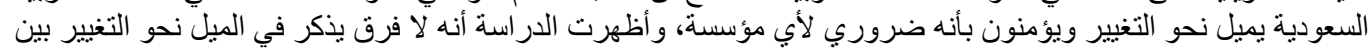

متغير ات الدر اسة جميعأ.

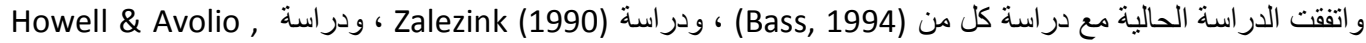

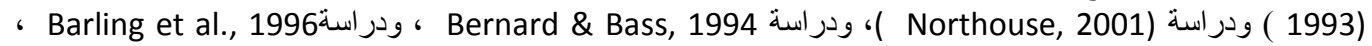

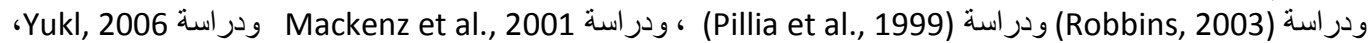

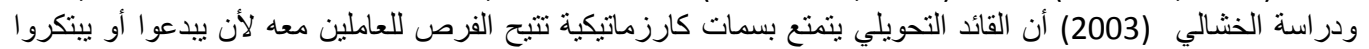

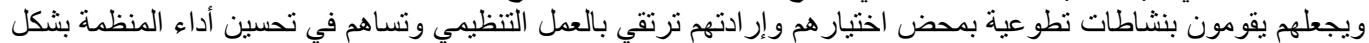

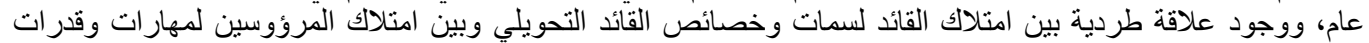

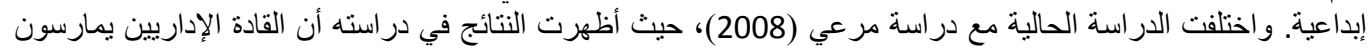

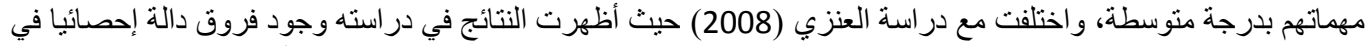

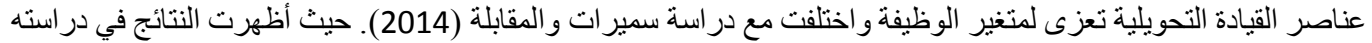
وجود فروق دالة إحصائيا في امتلاك خصائص وسمات القائد التحويلي تعزى إلى المؤهل العلى العي و الخبرة.

الخاتمة

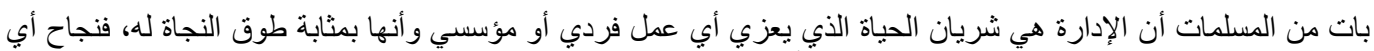

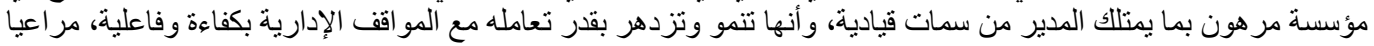

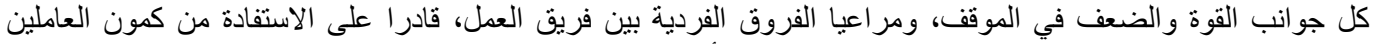

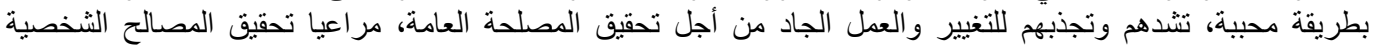

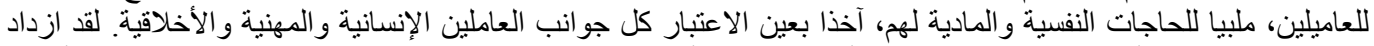

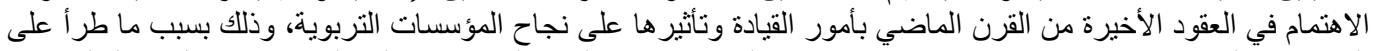

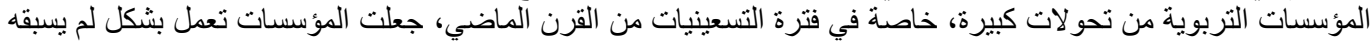
نظير في الحضارات السابقة، وذللك بسبب تتوع المناخ الثقافي والتنظيمي لتللك المؤسسات، من هذا المنطلق اجتهـ المختصون لتصني 
في علم الإدارة والباحثون فيه، بتحديد دور القيادة ووظيفتها تمهيداً لوجود مؤسسات تعليمية أكثر فعالية وأنجع أثراً، للاستعداد للتحو لات التي تطر أ يو ما بعد يوم على لته العالم من حولنا.

التوصيات

في ضوء نتائج الدراسة أوصى الباحثون بما يلي:

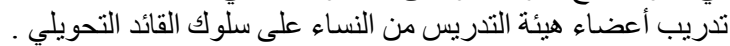

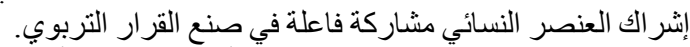

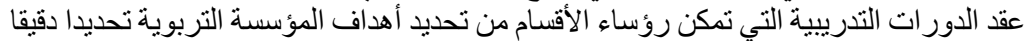

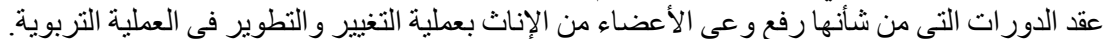

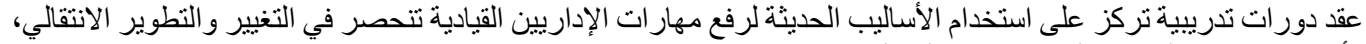
وأهمية الاعتناء بالعنصر البشري تبري في عملية التغيير. و أوصى الباحثّن بإجر اء المزيد من الدر اسات في المؤسسات التربوية المشابهة لجامعة الدمام لرفع مستوى الإداريين فيها.

أبو العسل ، عوض ـ(1993). الرضا الوظيفي لدى الاداريين العاملين في مديريات التربية و التعليم في المملكة العربية

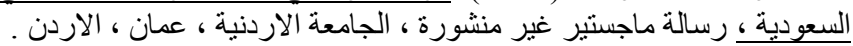

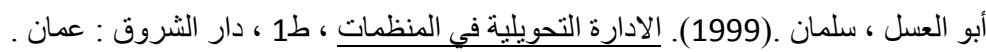

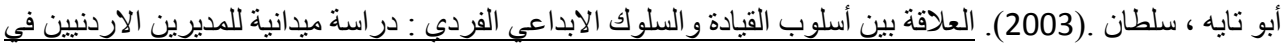

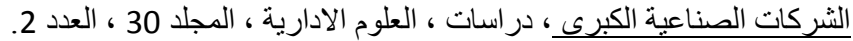

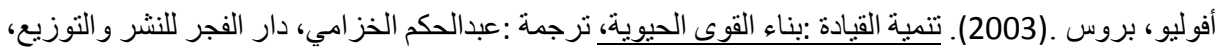

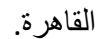
الخشالي ، شاكر و التميمي ، إياد .( 2008). أثر القيادة في التعلم التنظيمي دراسة ميدانية في شركات القطاع الصناعي الاردني، المجلة الاردنبة في ادارة الاعمال ، المجلد 4 ، العدد التياد 2.

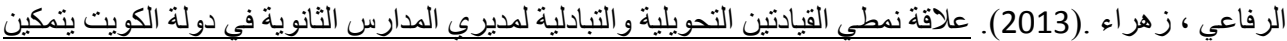

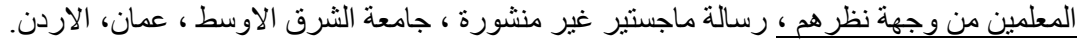

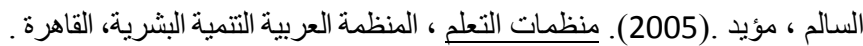

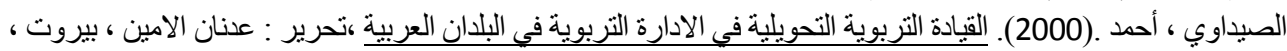
الهيئة اللبنانية للعلوم التربوية. الطيان ، سوسن .(2000) ـ البيئة و الأداء، رسالة ماجستير غبر منشورة الجامعة الأردنية، عمان، الأردن.

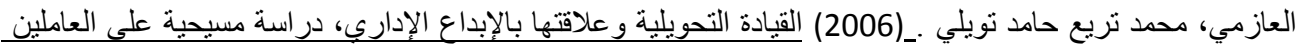

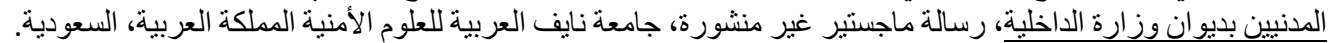

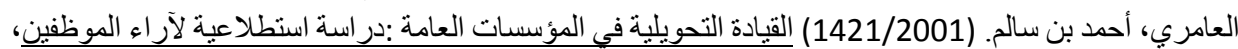

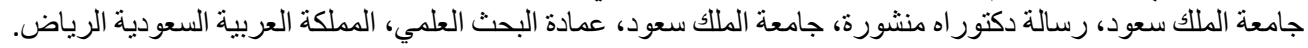

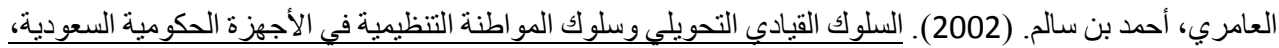

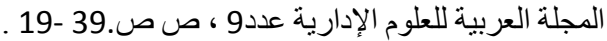

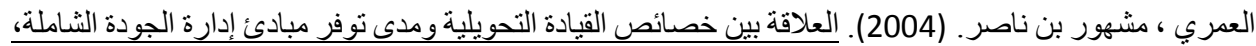

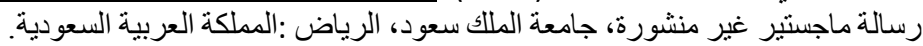

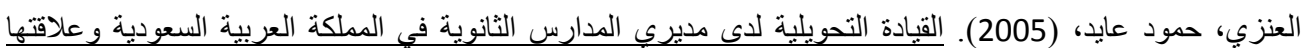

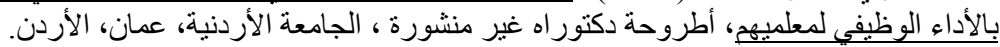

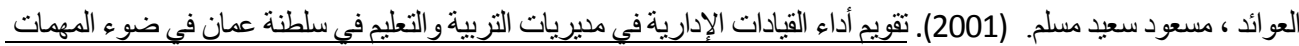

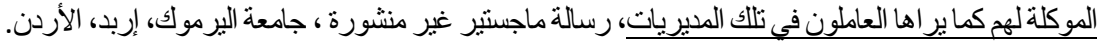

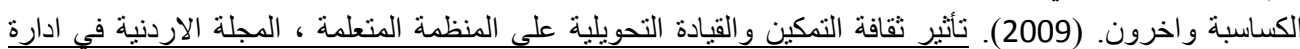
الاعمال ، المجلد 5، العدد 1 . الترون

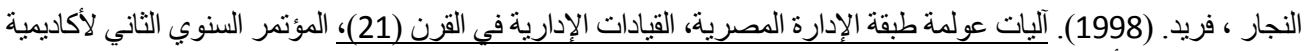
السادات للعلوم الإدارية، أكاديمية السادات للعلوم الإدارية، القاهرة. 


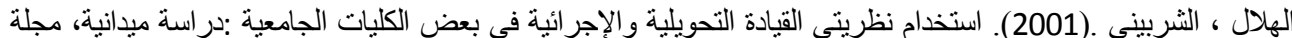

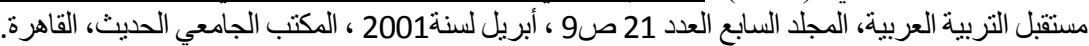

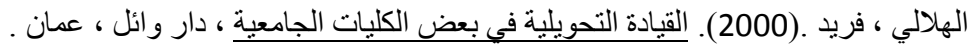

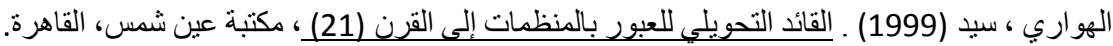

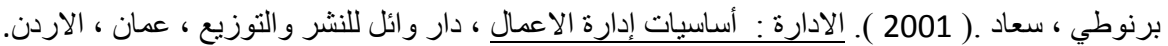

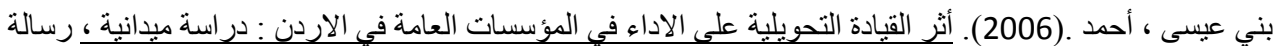

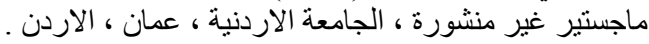

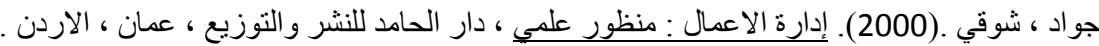

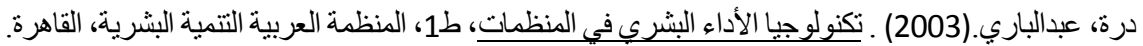

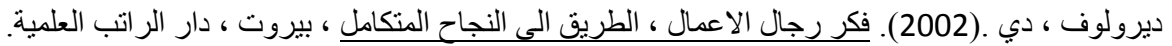

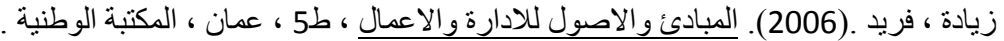

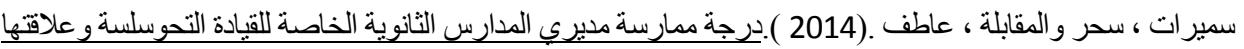

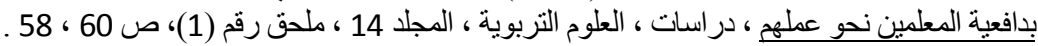

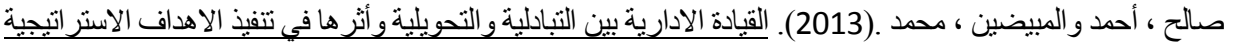

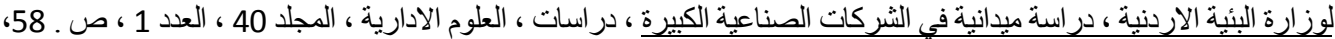

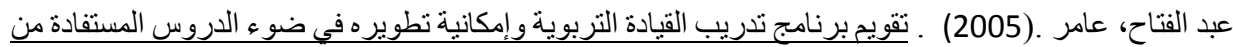

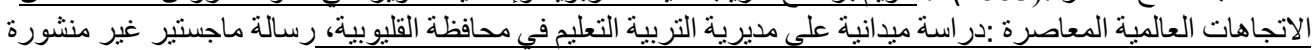
،جامعة عين شمس ، مصر ، القاهرة.

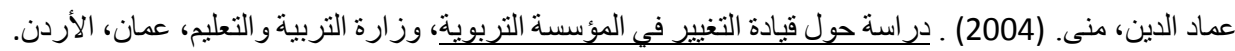

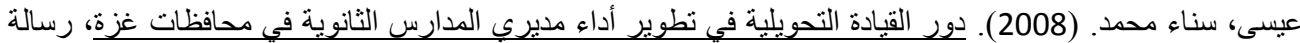
ماجستير غير منشورة، غزة، الجامعة الإسلامية.

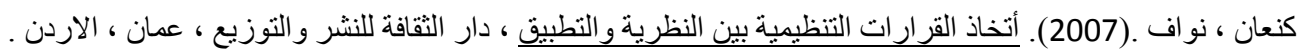

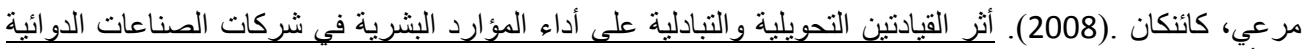

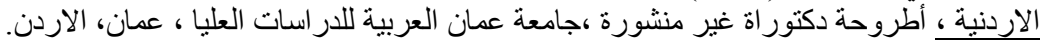

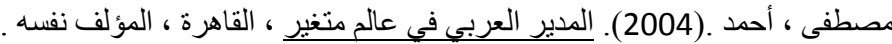
منتدى الفكر العربي. (1991) ـ تعليم الأمة العربية في القرن الحادي و العشرين، الكارثة أو الأمل، عمان، الأردن.

AL-Syaidh, N., Masa'deh, R., and Al-Zu'bi, Z. Transformational Leadership and its Impact on the Effectiveness of Employees' Behavior in the Public and Private Jordanian Hospitals. Jordan Journal of Business Administration, 11 (1), pp. 23-57, 2015.

Aminuddin, Y. The Relationship between Transformational Leadership Behaviours of Athletic Directors and Coaches Job Satisfaction: A Field Study, Physical Educator, Canada, 55 (4), 1998.

Barling, J., Weber, J., and Kelloway, E. Effects of Transformational Leadership Training on Attitudinal and Financial Outcomes: A Field Experiment. Journal of Applied Psychology, 81 (6), 1996.

- $\quad$ Bass, Bernard, Improving Organizational Effectiveness through Transformational Leadership, London Sage Publications, 1994.

Bass, B. M., and Avolio, B. J. Improving Organizational Effectiveness through Transformational Leadership, Sage, Thousand Oaks, CA, 1994.

- $\quad$ Bass, B., and Avolio, B. The Full range Leadership Development Manual for the Multifactor Leadership Questionnaire, Mindgarden: Redwood City, CA, 1997.

Bratton, J., Grint, K., and Nelson, D. L. Organizational Leadership. United States: Library of Congress Publishing, 2005. 
- $\quad$ Colvin, Ropper, Transformational Leadarship: A Prescription for Contempoary

Organizations, Leadarship Quarterly, 9 (1), 1999.

- $\quad$ Daft, Richard, Organizational Theory and Desing, $11^{\text {th }}$ eds., U.S.A. 2004.

- $\quad$ Eden, D. Leadership and Expectations: Pygmalion Effects and other Self-Fulfilling Prophecies in Organization, Leadership Quarterly, 3, pp. 271-335, 1992.

- $\quad$ Edwards, G., and Gill, R. Transformational Leadershipacross Hierarchical Levels in UK Manufacturing Organizations, Leadership and Organizational Development Journal, 33 (1), 2011.

- $\quad$ Howell, J.U., and Avolio, B.J. Transformational Leadership Transactional Leadership, locus of control and support for innovation. Journal of Applied Psychology, 78, 1993.

- $\quad$ Kajs, L T., and McCollum, D. A Confirmatory Factor Analytic Study of the Goal Orientation Theory of Motivation in Educational Leadership, Educational Research Quarterly, 33(1), pp. 3-17, 2009.

- $\quad$ Krejcih, R., and Morgan, D. Determining Sample Size for Research Activities. Educational and Psychological Measurement, 30, pp. 607-610, 1970.

- $\quad$ Leithwood, K. Transformational Leadership, Where Does it Stand? Education Digest, 58 (3), pp. 17-20, 1992.

- $\quad$ Leithwood, K. Leadership for the School Restructuring, Educational Administration Quarterly, 30 (4), 1994.

- $\quad$ Mackenz, S., Podsakoffm, O., and Richm, G. Transformational and Transactional Leadership and Salesperson performance, Academy of Marketing Sceience Journal, 2001.

- $\quad$ Masa'deh, R., Obeidat, B., Zyod, D., and Gharaibeh, A. The Associations among Transformational Leadership, Transactional Leadership, Knowledge Sharing, Job Performance, and Firm Performance: A Theoretical Model. Journal of Social Sciences (COES\&RJ-JSS), 4 (2), pp. 848-866, 2015.

- $\quad$ Nischan, T.P. Transformational Leadership as a Predictor of Effectiveness Extra Effort and Satisfaction in a Community College classroom Environment, Unpublished Doctoral Dissertation, Nova Southeastern University, USA, 1997.

- $\quad$ Northouse, P.G. Leadership Theory and Practice, Thousand Oaks, CA: Sage Publications Inc., 2001.

- $\quad$ Pillia, R., Schriesheim, C., and Williams, E. Fairness Perciptions and Trust for Transformational and Transactional Leadarship, Journal of Manjment, 9 (2), 1999.

- $\quad$ Podsakoff, P. M., and MacKenzie, S. Transformational Leader Behaviors and Substitutes for Leadership as Determinanta of Employee Satisfaction, Commitment, Trust and Organizational Citizenship Behaviors, Journal of Management, 22 (1), pp. 259-298, 1996.

- $\quad$ Robbins, S. P. Organizational Behavior. New Jersey: Pearson Education International, 2003.

- $\quad$ Roberts, N. Transforming Leadership: APO cess of Collective Action, Human Relation, 1985.

- $\quad$ Sagnak, M. The Relationship between Transformational School Leadership and Ethical Climate, Kuram ve Uygulamada Egitim Bilimleri, Educational Sciences: Theory and Ractice, 10 (2), 1135-1152, 2010.

- $\quad$ Seltzer, J., and Bass, B. Transformational Leadership, Transactional Leadership, Locus of Control, and support for Innovation, Journal of Applied Psychology, 78, 1990.

Tichy, N. M., and Devanna, M. A. The Transformational Leadership, John Wiley, New York, 1990. 
The degree of heads of departments at the University....

- $\quad$ Yee, D. In Saskatchewan: Chalk, Chips, and Children, Reshaping School Leadership, 55 (7), 1998.

- $\quad$ Yukl, G. Leadership in Organizations, $6^{\text {th }}$ eds., New Jersey, Pearson Prentice Hall, 2006.

- $\quad$ Zalezink, A. The Leadership Gap, The Executive, 4, 1990.

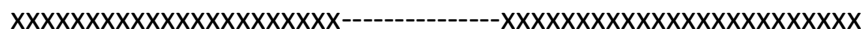

